\title{
Supplementation of nicotinic acid to prepartum Holstein cows increases colostral immunoglobulin G, excretion of urinary purine derivatives, and feed efficiency in calves
}

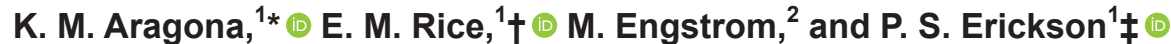 \\ ${ }^{1}$ Department of Agriculture, Nutrition and Food Systems, University of New Hampshire, Durham 03824 \\ ${ }^{2}$ DSM Nutritional Products, North America, 45 Waterview Boulevard, Parsippany, NJ 07054
}

\begin{abstract}
We evaluated the effects of incremental levels of unprotected nicotinic acid (NA) supplementation prepartum $(0,16,32$, or $48 \mathrm{~g} / \mathrm{d}$; CON $, 16 \mathrm{NA}, 32 \mathrm{NA}$, and 48NA, respectively) on colostrum yield and composition and cow and calf performance. Previous research indicated that $48 \mathrm{~g} / \mathrm{d}$ of NA prepartum increased colostrum IgG concentration. Exact mechanisms for this increase are not clear. The effects of NA supplementation to prepartum cows on growth and performance of their calves have not been studied. Thirty-six multiparous Holstein cows housed in a tie-stall barn were blocked by expected calving date and randomly assigned to treatments at 4 wk prepartum. Blood samples were collected 3 times weekly for analysis of nonesterified fatty acids, ketones, and IgG. Urine samples were also collected 3 times weekly for analysis of creatinine and purine derivatives. Colostrum was collected within 90 min after parturition. Calves were removed from their dams before suckling, weighed within $30 \mathrm{~min}$ of birth, and received $4 \mathrm{~L}$ of maternal colostrum. The 38 calves born were blocked based on treatments of dams. All calves were fed $449 \mathrm{~g}$ dry matter (DM) of milk replacer ( $19.3 \%$ crude protein, $19.5 \%$ fat, DM basis) and a textured starter (41\% starch, DM basis) at $2 \mathrm{~d}$ of age until weaning at $42 \mathrm{~d}$, with water available ad libitum. Feeding NA resulted in linear decreases in DM intake in cows, but colostrum yield was not affected. Yield of metabolizable energy (ME) tended to change cubically, decreasing from control (CON) to 16NA, increasing from $16 \mathrm{NA}$ to $32 \mathrm{NA}$, and decreasing from
\end{abstract}

Received June 3, 2019.

Accepted October 23, 2019

*Current address: Provimi North America, 10 Nutrition Way, Brookville, OH 45309

†Current address: Department of Animal Science, University of Kentucky, Lexington 40546

‡Corresponding author: peter.erickson@unh.edu
$32 \mathrm{NA}$ to $48 \mathrm{NA}$. Concentration of $\mathrm{IgG}$, protein, ash, and solids increased linearly with NA. Concentration of ME showed a tendency to increase quadratically with NA. Yield of IgG, fat, protein, and solids content increased quadratically with NA, while allantoin and total purine derivatives increased linearly. Calf $24-\mathrm{h} \operatorname{IgG}$ and apparent efficiency of absorption were not affected by NA. Calf ME intake from colostrum tended to increase quadratically with NA, but calf starter intake was not affected. Feed efficiency of calves increased quadratically with NA. Calf average daily gain changed cubically with NA, decreasing from CON to $16 \mathrm{NA}$, increasing from 16NA to $32 \mathrm{NA}$, and decreasing from $32 \mathrm{NA}$ to 48NA. Hip width gain, body length gain, and final body length changed cubically with NA, decreasing from CON to 16NA, increasing from 16NA to 32NA, and decreasing from $32 \mathrm{NA}$ to $48 \mathrm{NA}$. Calf blood concentrations of ketones increased quadratically with NA. These data suggest that increasing levels of NA can be fed prepartum to increase colostral components and 32 g/d NA can improve calf performance.

Key words: prepartum cow, nicotinic acid, colostrum, purine derivative, calf

\section{INTRODUCTION}

For successful growth and production, the immunologically naïve newborn calf must consume high-quality colostrum as soon as possible after birth. In the United States, $>60 \%$ of colostrum fails to meet industry standards to be considered high quality ( $\geq 50 \mathrm{~g} / \mathrm{L} \mathrm{IgG}$, total plate count of $<100,000 \mathrm{cfu} / \mathrm{mL}$; Morrill et al., 2012). Colostrum quality in Norway, Australia, and Ireland also does not meet these standards (Gulliksen et al., 2008; Phipps et al., 2016; Dunn et al., 2017), indicating a global need for improvement. In some cases, the B vitamin nicotinic acid (NA) increased milk protein production in cattle (Riddell et al., 1981; Erickson et al., 1992; Karkoodi and Tamizrad, 2009; Niehoff et al., 2009b), which was attributed to greater microbial 
protein production (Riddell et al., 1981) and increased vasodilation (Tunaru et al., 2003; Benyó et al., 2006). These combined effects may lead to an increase in available protein, in the form of AA for production of IgG, as well as increased flow of nutrient-rich blood to the mammary gland, thereby increasing colostrum quality. Previously, colostral IgG was increased by $18 \%$ when $48 \mathrm{~g} / \mathrm{d}$ NA was supplemented prepartum (Aragona et al., 2016).

Most mammals synthesize NA from tryptophan or quinolinic acid, but cattle are inefficient at the conversion owing to high picolinic acid carboxylase activity (Frye et al., 1991; Flachowsky, 1993). Production of both forms of niacin, including NA and nicotinamide, by the rumen bacteria of a $650-\mathrm{kg}$ cow producing 35 $\mathrm{kg} / \mathrm{d}$ of FCM is estimated to be $1,804 \mathrm{mg} / \mathrm{d}$ (NRC, 2001), but the estimate is based on work with steers (NRC, 2001). Requirements also have not been determined experimentally but are instead estimated based on work with lactating sows (NRC, 2001). Other than the diet, microbial synthesis serves as a significant source of NA. However, de novo synthesis of NA is an energy-demanding process and rumen bacteria may synthesize only what they require for growth and function (Hannah and Stern, 1985; Abdouli and Schaefer, 1986; Doreau and Ottou, 1996). A diet deficient in NA or tryptophan may affect proliferation of protozoa because they are unable to synthesize NA (Doreau and Ottou, 1996). Although protozoa are not necessary, they are part of a normal rumen ecosystem, where they have a synergistic relationship with rumen bacteria that enhances fermentation. The rumen protozoa population, specifically entodinia, was increased by NA supplementation (Erickson et al., 1990). Entodinia engulf starch particles, leading to a slow release of acetic acid that helps maintain rumen $\mathrm{pH}$ (Williams and Coleman, 1992; Dehority, 2003). Stable pH supports proliferation of rumen microbes and may increase microbial crude protein (MCP) production, which provides the majority of absorbable AA in the small intestine of the cow (Fatahnia et al., 2012). Additional AA during colostrogenesis may increase IgG in colostrum, as immunoglobulins are composed of hundreds of AA.

Colostrogenesis is a unique stage in prepartum mammary gland development during which maternal IgG are transferred from blood into mammary secretions (Barrington et al., 2001). It begins 3 to 4 wk prepartum and ceases just before calving (Brandon et al., 1971). A 6-layer epitheliochorial placenta prevents transfer of maternal immunoglobulins to the fetus, so it is imperative that newborn calves receive high-quality colostrum immediately after birth because immunoglobulin absorption ceases around $24 \mathrm{~h}$ of age (Arthington et al.,
2000). Calves that do not receive high-quality colostrum fail to absorb adequate amounts of IgG, which increases morbidity and mortality and decreases growth and milk production in the first and second lactations (Robison et al., 1988; DeNise et al., 1989). Providing greater quality colostrum to ensure proper health, growth, and development in early life is critical to subsequent health and productivity.

The objectives of this experiment were to (1) evaluate the effects prepartum NA supplementation on colostrum yield, composition, and cow and calf performance and (2) determine the effects of NA on microbial protein production, estimated using excretion of urinary purine derivatives (PD), an internal metabolic marker. Our hypothesis was that supplemental NA would increase colostrum quality and would have a positive effect on the growth of calves. We hypothesized that supplementing NA would lead to increased microbial protein production, estimated by an increase in urinary PD.

\section{MATERIALS AND METHODS}

\section{Experimental Design and Animal Management}

This experiment was reviewed and approved by the University of New Hampshire Institutional Animal Care and Use Committee (Protocol no. 151101). It was conducted at Fairchild Dairy Teaching and Research Center at the University of New Hampshire in Durham, from February 2016 to March 2017.

Thirty-six multiparous Holstein cows were blocked by expected calving date and randomly assigned to 1 of 4 treatments, each mixed with $40 \mathrm{~g} / \mathrm{d}$ of corn meal as a carrier $(\mathrm{n}=9)$ : (1) $0 \mathrm{~g} / \mathrm{d} \mathrm{NA}$ (control, CON), (2) $16 \mathrm{~g} / \mathrm{d}$ NA (16NA), (3) $32 \mathrm{~g} / \mathrm{d} \mathrm{NA}$ (32NA), or (4) 48 $\mathrm{g} / \mathrm{d}$ NA (48NA). Nicotinic acid fed in this trial was an unprotected form. Treatments were top dressed at each feeding daily between 0700 and $0730 \mathrm{~h}$, beginning 4 wk prepartum and continuing until calving. Previously, feeding $48 \mathrm{~g} / \mathrm{d}$ NA to prepartum cows was associated with an increased IgG concentration in colostrum compared with cows receiving no NA. Therefore, incremental amounts of NA were fed to further delineate the dose needed to observe this result. Days on study did not differ between treatments and averaged 25, 27, 26, and 26 for CON, 16NA, 32NA, and 48NA, respectively. Cows were housed in a tie-stall barn, and stalls had mattresses bedded with kiln-dried sawdust. Cows had ad libitum access to water via automated water bowls (DeLaval, Tumba, Sweden). Each cow was fed via an individual wooden feed tub (measuring $90 \times 90 \times 90$ $\mathrm{cm}$ ) that allowed for measurements of daily feed intake. Cows were moved to individual maternity pens as they 
neared calving, which also allowed for measurements of individual daily feed intake and other measurements.

\section{Feed Sampling and Analyses}

The diet was formulated to meet the nutrient requirements for close-up prepartum dairy cows (NRC, 2001). It contained $42.6 \%$ corn silage, $24.2 \%$ grass haycrop silage, $1.3 \%$ RUP mix, $0.3 \%$ energy mix, $1.3 \%$ soy/ urea, and $29.9 \%$ close-up dry cow mix on a DM basis (Table 1). The study lasted for $13 \mathrm{mo}$; therefore, the diet was adjusted as needed based on DM of forages. Total mixed ration amounts fed and refused were measured daily between $0700 \mathrm{~h}$ and $0730 \mathrm{~h}$ to determine DMI. Amount of feed offered each day was adjusted to achieve 5 to $10 \%$ refusals. Samples of the TMR and orts were collected daily and frozen at $-20^{\circ} \mathrm{C}$ until further analysis. Frozen samples were thawed at room temperature and dried in a forced hot air convection oven (Binder, Bohemia, NY) at $55^{\circ} \mathrm{C}$ for $48 \mathrm{~h}$ to determine DM. Ort samples were composited weekly by cow based on DM, and TMR samples were composited monthly based on DM. All samples were ground through a 1-mm screen using a Wiley mill (Arthur H. Thomas Scientific, Swedesboro, NJ). Samples were sent to a commercial forage laboratory for nutritional analyses (Dairy One Forage Laboratory, Ithaca, NY) of absolute DM (method 930.15; AOAC International, 2006); NDF (method 6 in an Ankom Fiber Analyzer A2000 with $\alpha$-amylase and sodium sulfite; Ankom Technology, Fairpoint, NY; solutions as in Van Soest et al., 1991); ADF (method 5 in an Ankom Fiber Analyzer A2000; Ankom Technology; method 973.18, AOAC International, 1998); CP (method 990.03, AOAC International, 2006); starch (via Trinder glucose oxidase enzymatic method using YSI 2700 Select Biochemistry Analyzer, YSI Inc. Life Sciences, Yellow Springs, OH); ether extract (method 2003.05, AOAC International, 2006); ash (method 942.05, AOAC International, 2006); and $\mathrm{Ca}, \mathrm{P}, \mathrm{Mg}, \mathrm{K}$, and $\mathrm{S}$ (CEM Microwave Accelerated Reaction System followed then analyzed by inductively coupled plasma MS using Thermo Scientific iCAP 6300 Inductively Coupled Plasma Radial Spectrometer; Chelmsford, MA).

\section{Cow Blood Sampling and Analyses}

All cows were weighed before starting treatments (Cardinal Scale, Northeast Scale Co. Inc., Hooksett, $\mathrm{NH}$ ) and every Monday thereafter until calving. Change in BW was calculated by subtracting BW before treatment administration (covariate BW) from the last BW taken on the Monday before calving. Once cows were assigned to treatments, blood samples were collected every Monday, Wednesday, and Friday between 1000 and $1030 \mathrm{~h}$ ( 3 to $3.5 \mathrm{~h}$ after feeding), at calving, and $24 \mathrm{~h}$ and $7 \mathrm{~d}$ postpartum. Blood samples were collected via coccygeal vein or artery into two $10-\mathrm{mL}$ evacuated tubes, one containing EDTA and one with no additive (Monoject, Covidien, Mansfield, MA). Blood samples were immediately placed on ice and transported to the laboratory. A small aliquot of whole blood was taken from the $10-\mathrm{mL}$ tube with no additive for immediate analysis of ketones using a NovaMax Plus Ketone meter (Nova Biomedical, Waltham, MA). Both tubes were

Table 1. Ingredient and chemical composition (\% of DM unless otherwise noted; $\pm \mathrm{SD}$ ) of the prepartum diet

\begin{tabular}{|c|c|}
\hline Item & Value \\
\hline \multicolumn{2}{|l|}{ Dietary ingredient } \\
\hline Corn silage & $42.5 \pm 2.5$ \\
\hline Grass haylage & $24.2 \pm 1.3$ \\
\hline RUP $\operatorname{mix}^{1}$ & $1.3 \pm 0$ \\
\hline Dry cow $\operatorname{mix}^{2}$ & $29.9 \pm 0$ \\
\hline Energy $\operatorname{mix}^{3}$ & $0.3 \pm 0.4$ \\
\hline Protein $\operatorname{mix}^{4}$ & $1.3 \pm 0.4$ \\
\hline \multicolumn{2}{|l|}{ Nutrient content } \\
\hline $\mathrm{CP}$ & $15.3 \pm 0.9$ \\
\hline $\mathrm{ADF}$ & $26.3 \pm 2.8$ \\
\hline $\mathrm{NDF}$ & $40.3 \pm 3.9$ \\
\hline NFC & $33.3 \pm 3.3$ \\
\hline Starch & $20.9 \pm 2.5$ \\
\hline Fat & $3.5 \pm 0.5$ \\
\hline Ash & $7.6 \pm 0.5$ \\
\hline $\mathrm{Ca}$ & $0.7 \pm 0.08$ \\
\hline $\mathrm{P}$ & $0.3 \pm 0.03$ \\
\hline $\mathrm{Mg}$ & $0.6 \pm 0.03$ \\
\hline $\mathrm{K}$ & $1.6 \pm 0.2$ \\
\hline $\mathrm{Na}$ & $0.2 \pm 0.03$ \\
\hline $\mathrm{S}$ & $0.5 \pm 0.05$ \\
\hline $\mathrm{Cl}$ & $0.8 \pm 0.08$ \\
\hline $\mathrm{Fe}(\mathrm{mg} / \mathrm{kg})$ & $230.9 \pm 50.4$ \\
\hline Zn (mg/kg) & $65.4 \pm 4.8$ \\
\hline $\mathrm{Cu}(\mathrm{mg} / \mathrm{kg})$ & $14.9 \pm 1.4$ \\
\hline $\mathrm{Mn}(\mathrm{mg} / \mathrm{kg})$ & $64.9 \pm 5.5$ \\
\hline DCAD $(\mathrm{mEq} / 100 \mathrm{~g})$ & $-1.9 \pm 6.4$ \\
\hline
\end{tabular}

${ }^{1}$ RUP mix: $97.1 \%$ blood meal and 2.9\% Smartamine M (Adisseo, Antony, France).

${ }^{2}$ Prefresh mix: $22.15 \%$ beet pulp, $21.60 \%$ corn meal, $15.12 \%$ soybean meal, 10.8\% distillers dried grain, 9.6\% Bio-Chlor (Church and Dwight, Princeton, NJ), 8.14\% Amino-Max (Agritech, Watertown, NY), $3.16 \%$ molasses, $2.63 \% \mathrm{CaSO}_{4}, 1.94 \% \mathrm{MgO}, 1.94 \% \mathrm{CaCO}_{3}, 1.09 \% \mathrm{MgSO}_{4}$, $0.95 \% \mathrm{NaCl}, \quad 0.47 \%$ vitamin/trace mineral premix (composition shown later), $0.36 \%$ vitamin $\mathrm{E}(88,200 \mathrm{IU} / \mathrm{kg})$, and $0.05 \%$ monensin [Rumensin $90(200 \mathrm{~g} / \mathrm{kg})$ Elanco, Greenfield, IN)]. Vitamin/trace mineral premix: $20.61 \% \mathrm{Ca}, 2.54 \% \mathrm{Zn}, 2.18 \% \mathrm{Mn}, 0.85 \% \mathrm{Cl}, 0.69 \% \mathrm{Mg}$, $0.16 \% \mathrm{P}, 0.15 \% \mathrm{~S}, 6,430 \mathrm{mg} / \mathrm{kg} \mathrm{Cu}, 427 \mathrm{mg} / \mathrm{kg} \mathrm{I}, 269 \mathrm{mg} / \mathrm{kg} \mathrm{Se}, 154$ $\mathrm{mg} / \mathrm{kg}$ Co, 5,734 kIU/kg vitamin A, $1,589 \mathrm{kIU} / \mathrm{kg}$ vitamin $\mathrm{D}_{3}, 29.8$ $\mathrm{kIU} / \mathrm{kg}$ vitamin $\mathrm{E}$, and $1.80 \mathrm{mg} / \mathrm{kg}$ choline.

${ }^{3}$ Energy mix: $45.80 \%$ corn meal, $33.99 \%$ beet pulp, $15.2 \%$ steam flaked corn, and $5.01 \%$ molasses.

${ }^{4}$ Protein mix: $69.14 \%$ soybean meal, $21.83 \%$ canola meal, $7.28 \%$ distillers dried grains, and $1.75 \%$ urea. 
centrifuged at $1,278 \times g$ at $4^{\circ} \mathrm{C}$ for $20 \min$ (5430R, Eppendorf, Hamburg, Germany). Plasma and serum were aspirated and stored at $-20^{\circ} \mathrm{C}$ until further analysis for nonesterified fatty acid (NEFA) and IgG, respectively. Plasma concentration of NEFA (NEFA-HR 2, Wako Diagnostics, Mountain View, CA) was determined using a microplate reader (Chromate, Awareness Technology Inc., Palm City, FL). Serum concentration of IgG was determined using a radial immunodiffusion assay (Triple J Farms, Bellingham, WA).

\section{Urinary Sampling and Analyses}

Urine samples were collected before administration of treatment and every Monday, Wednesday, and Friday thereafter, between $1000 \mathrm{~h}$ and $1030 \mathrm{~h}$, via manual stimulation of the pudendal nerve. Urinary samples were immediately transported to the laboratory, where the $\mathrm{pH}$ was measured using an epoxy-body Sure-flow combination $\mathrm{pH}$ electrode probe (Orion Star A214 Benchtop pH/ISE Meter, Thermo Scientific). Following $\mathrm{pH}$ readings, a $2.8-\mathrm{mL}$ subsample of urine was pooled over $3 \mathrm{~d}$ into centrifuge tubes containing $33.6 \mathrm{~mL}$ of $0.072 \mathrm{~N} \mathrm{H}_{2} \mathrm{SO}_{4}$ for later analysis of creatinine, allantoin, uric acid, urea-N, and total N. Samples were thawed at room temperature and analyzed colorimetrically for concentrations of creatinine (assay kit no. 500701, Cayman Chemical Co., Ann Arbor, MI), using a microplate reader (Epoch, BioTek Instruments, Inc., Winooski, VT) set to a wavelength of $492 \mathrm{~nm}$, and concentrations of allantoin (Chen and Gomes, 1992), uric acid (assay kit no. 1045-225, Stanbio Laboratory, Boerne, TX), and urea-N (diacetyl-monoxime method), using an UV/ visible spectrophotometer (Genesys 10S Vis, Thermo Scientific) set at wavelengths of 522, 520, and $540 \mathrm{~nm}$, respectively. Total $\mathrm{N}$ was analyzed by Dairy One Forage Laboratory (micro-Kjeldahl analysis, AOAC International, 1990). A 14-mL subsample of urine was pooled over $3 \mathrm{~d}$ into centrifuge tubes containing $1.2 \mathrm{~mL}$ of $6 \mathrm{~N}$ $\mathrm{HCl}$ for later analysis of $\mathrm{NH}_{3}-\mathrm{N}$. Samples were thawed at room temperature and analyzed for $\mathrm{NH}_{3}-\mathrm{N}$ by adding $1 \mathrm{~mL}$ of $\mathrm{pH}$ ionic strength adjuster (Orion 951211, Thermo Scientific) to a beaker containing $10 \mathrm{~mL}$ of urine. Gaseous $\mathrm{NH}_{3}$ was measured using an electrode ammonia probe (9512HPBNWP, Orion Star A214 Benchtop pH/ISE Meter, Thermo Scientific). Urinary volume was estimated from the urinary concentration of creatinine, assuming a constant creatinine excretion rate of $25.23 \mathrm{mg} / \mathrm{kg}$ of $\mathrm{BW}$ for dry cows (Valadares et al., 1997, 1999). Urinary excretion of total purine derivatives was calculated by adding allantoin and uric acid excretion.

\section{Parturition: Colostrum Collection and Feeding}

Cows that experienced difficulty calving were not used in this study. Except for colostrum from one cow receiving $48 \mathrm{~g} / \mathrm{d}$ NA (also deemed an outlier and removed from statistical analysis), all colostrum was collected within 60 to 90 min of calving. Colostrum was weighed and 2 aliquots were immediately collected for future analysis. One aliquot was sent to Dairy One Laboratories and analyzed for fat (method 989.05), protein (method 991.20), solids (method 990.20), and ash (method 930.30) according to AOAC International methods (AOAC International, 2006). The second aliquot was frozen at $-20^{\circ} \mathrm{C}$ until further analysis of $\operatorname{IgG}$ concentration via radial immunodiffusion assay (Triple J Farms). Metabolizable energy of colostrum was estimated based on the ME calculation of milk (NRC, 2001).

Calves were removed within $30 \mathrm{~min}$ of birth and before nursing. Calves were weighed (A and A Scales LLC, Prospect Park, NJ) and placed into individual pens $(1 \times 2.15 \mathrm{~m})$ in a naturally ventilated enclosed calf room. Navels were dipped in a $7 \%$ iodine tincture. Calves received $4 \mathrm{~L}$ of maternal colostrum via nipple bottle within $2 \mathrm{~h}$ of birth. If calves did not immediately consume colostrum, it was kept warm and reintroduced $1 \mathrm{~h}$ later. If the remaining colostrum was refused, it was fed via esophageal tube.

The 38 calves born from study cows were blocked based on treatments of the dam. In total, 5 bull calves and 4 heifer calves ( 1 set of heifer twins but 1 was stillborn) were born from cows on CON; 5 bull calves and 5 heifer calves ( 1 set of freemartin twins) were born from cows on 16NA; 6 bull calves and 4 heifer calves ( 1 set of heifer twins) were born from cows in $32 \mathrm{NA}$; and 4 bull calves and 5 heifer calves, (2 sets of freemartin twins) were born from cows on 48NA. One bull and a set of heifer twins born from cows fed 48NA were removed from the study due to insufficient production of maternal colostrum, and therefore insufficient consumption, and are not included in the calf numbers above. All calves remained on study until weaning at d 42 .

\section{Calf Blood Sampling and Analyses}

At the time of parturition, a blood sample was collected from each calf at $0 \mathrm{~h}$ (before receiving maternal colostrum) and $24 \mathrm{~h}$ via jugular venipuncture into a $10-\mathrm{mL}$ tube with no additive (Monoject). The blood was allowed to clot before being centrifuged at 1,278 $\times g$ at $4^{\circ} \mathrm{C}$ for $20 \mathrm{~min}$ (5430R, Eppendorf, Hamburg, Germany). Serum was aspirated and stored at $-20^{\circ} \mathrm{C}$ 
until further analysis for IgG via radial immunodiffusion assay. Apparent efficiency of absorption at $24 \mathrm{~h}$ of age was estimated using the following equation, according to Quigley et al. (1998):

$$
\begin{gathered}
\{[24 \text {-h serum } \operatorname{IgG}(\mathrm{g} / \mathrm{L}) \times \mathrm{BW}(\mathrm{kg}) \times 0.09] / \\
\operatorname{IgG} \text { intake }(\mathrm{g} / \mathrm{L})\} \times 100 .
\end{gathered}
$$

Calf blood samples were also collected every Monday, Wednesday, and Friday between 0900 and 1000 h. Blood samples were collected via jugular venipuncture into a $10-\mathrm{mL}$ tube with no additive (Monoject). Tubes were placed on ice and transported to the laboratory, where blood was analyzed within $60 \mathrm{~min}$ for ketones using a NovaMax Plus Ketone meter.

\section{Calf Skeletal Measurements}

Calf body weight (VS-2000, A and A Scales LLC) was recorded at birth and weekly thereafter at $1000 \mathrm{~h}$. Skeletal measurements were taken weekly throughout the study at $0930 \mathrm{~h}$. Withers and hip height were taken with a sliding scale height stick with a bubble level, hip width was taken using a Hip-o-Meter (Dairy Innovations, Attica, NY), and body length and heart girth were taken with a weight tape.

\section{Calf Feeding, Sampling, and Analyses}

All calves were fed $449 \mathrm{~g}$ DM of a conventional milk replacer (MR; $19.3 \%$ CP, $19.5 \%$ fat, DM basis; Table 2 ) medicated with lasalocid that was provided by Provimi North America (Brookville, OH). Calves were fed MR twice daily between 0615 and $0645 \mathrm{~h}$ and again between 1545 and $1615 \mathrm{~h}$ and were weaned at $42 \mathrm{~d}$. Calves were fed an $18 \%$ CP textured starter, medicated with decoquinate (Provimi North America; Table 2) and water ad libitum starting at $2 \mathrm{~d}$ of age until weaning at $42 \mathrm{~d}$. The starter contained whole corn and oats, molasses, and a protein pellet. The amount of starter and water fed and refused was measured daily between 0615 and $0645 \mathrm{~h}$.

Starter samples were taken every time a new bag was opened. Starter ort samples were taken weekly. Starter samples were dried in a forced hot-air convection oven at $55^{\circ} \mathrm{C}$ for $48 \mathrm{~h}$ (Binder, Bohemia, NY) to determine DM for DMI calculations. Samples were ground through a 1-mm screen using a Wiley mill (Thomas Scientific, Swedesboro, NJ) and composited. Starter samples were sent to Dairy One Forage Laboratory for analysis of ADF, NDF, CP, starch, crude fat, Ca, P, $\mathrm{Mg}, \mathrm{K}$, and $\mathrm{S}$, as previously described. Milk replacer was sent to Analab (Fulton, IL), where fat was determined by saponification with $\mathrm{KOH}$ in ethyl alcohol; $\mathrm{HCl}$ was used to liberate the fat from the soaps, which was then extracted with petroleum ether. Milk replacer was also analyzed for CP, crude fat, and ash, as previously described.

\section{Statistical Analysis}

Cow Data. Data were analyzed using the MIXED procedure of SAS 9.4 (SAS Institute Inc., Cary, NC) according to a randomized complete block design, unless otherwise stated. Blood and urinary metabolites, cow BW, and DMI were analyzed as repeated measures according to the following model:

$$
\begin{aligned}
\mathrm{Y}_{i j k l}=\mu & +\mathrm{B}_{i}+\mathrm{TRT}_{j}+\mathrm{W}_{k}+\mathrm{L}_{l}+\beta \mathrm{X}_{i j} \\
& +\mathrm{TRT} \times \mathrm{W}_{j k}+\mathrm{e}_{i j k l},
\end{aligned}
$$

where $\mathrm{Y}_{i j k l}=$ the dependent variable, $\mu=$ the overall mean, $\mathrm{B}_{i}=$ the random effect of the $i$ th block, $\mathrm{TRT}_{j}$ $=$ the fixed effect of the $j$ th treatment level, $\mathrm{W}_{k}=$ the fixed effect of the $k$ th week relative to calving, $\mathrm{L}_{l}=$ the fixed effect of the $l$ th lactation, $\beta=$ the regression (covariate coefficient), $\mathrm{X}_{i j}=$ the covariate measurement; TRT $\times \mathrm{W}_{j k}=$ the fixed interaction between the $j$ th treatment level and the $k$ th week, and $\mathrm{e}_{i j k l}=$ the residual error term. All variables, except BW change and urinary uric acid concentration, were modeled using a compound symmetry covariance spatial structure, which resulted in the smallest Bayesian information criteria of the covariate structures tested: compound symmetry, first-order autoregressive, unstructured, and Toeplitz. Change in cow BW and urinary uric acid concentration were modeled using first-order autoregressive and Toeplitz, respectively, because they resulted in the smallest Bayesian information criteria. Degrees

Table 2. Nutrient analysis of calf starter, starter orts, and milk replacer (DM basis)

\begin{tabular}{lccc}
\hline Item & Starter $^{1}$ & $\begin{array}{c}\text { Starter } \\
\text { orts }\end{array}$ & $\begin{array}{c}\text { Milk } \\
\text { replacer }\end{array}$ \\
\hline CP & 20.4 & 19.1 & 19.3 \\
ADF & 8 & 8.5 & - \\
NDF & 13.9 & 12.8 & - \\
NFC & 53.8 & 57.5 & - \\
Starch & 40.8 & 45.2 & - \\
Crude fat & 4.3 & 4.1 & 19.5 \\
Ash & 7.7 & 6.6 & 5.4 \\
\hline
\end{tabular}

${ }^{1}$ Ingredient composition of starter (as fed): $37 \%$ whole corn, $35 \%$ supplement pellet, $25 \%$ whole oats, and $3 \%$ molasses; supplement pellet contained: $66 \%$ soybean meal, $22 \%$ wheat middlings, $9 \%$ minerals and vitamins, and $3 \%$ molasses. 
of freedom were calculated using the Kenward-Roger approximation option of the MIXED procedure.

Urine $\mathrm{pH}$ data were transformed into $\mathrm{H}^{+}$ion concentration (Murphy, 1982) and analyzed using the GLM procedure according to the following model:

$$
\mathrm{Y}_{i j k}=\mu+\mathrm{B}_{i}+\mathrm{TRT}_{j}+\mathrm{W}_{k}+\mathrm{TRTW}_{j k}+\mathrm{e}_{i j k},
$$

where $\mathrm{Y}_{i j k}=$ the dependent variable, $\mu=$ the overall mean, $\mathrm{B}_{i}=$ the random effect of the $i$ th block, TRT $_{j}$ $=$ the fixed effect of the $j$ th treatment level, $\mathrm{W}_{k}=$ the fixed effect of the $k$ th week relative to calving, TRTW $_{j k}$ $=$ the fixed interaction between the $j$ th treatment level and the $k$ th week, and $\mathrm{e}_{i j k}=$ the residual error term.

Colostrum IgG and ME concentration and yield; colostrum volume; and fat, protein, solids nonfat, ash, and lactose contents and yields were analyzed according to the following model:

$$
\mathrm{Y}_{i j}=\mu+\mathrm{B}_{i}+\mathrm{TRT}_{j}+\beta \mathrm{X}_{i j}+\mathrm{e}_{i j}
$$

where $\mathrm{Y}_{i j}=$ the dependent variable, $\mu=$ the overall mean, $\mathrm{B}_{i}=$ the random effect of $i$ th block, $\mathrm{TRT}_{j}=$ the fixed effect of the $j$ th treatment level, $\beta=$ the regression (covariate coefficient), $\mathrm{X}_{i j}=$ the covariate measurement, and $\mathrm{e}_{i j}=$ the residual error term. In this model, the random effect of cow within block subclass was used as the error term for the effect of treatment. Degrees of freedom were calculated using the KenwardRoger approximation option of the MIXED procedure.

Calf Data. Data were analyzed using the MIXED procedure of SAS 9.4 (SAS Institute Inc., Cary, NC) according to a randomized complete block design, unless otherwise stated. Initial calf BW, 0-h and 24-h IgG concentrations, apparent efficiency of absorption, and ME intake from colostrum were analyzed according to the following model:

$$
\mathrm{Y}_{i j}=\mu+\mathrm{B}_{i}+\beta \mathrm{X}_{i j}+\mathrm{TRT}_{j}+\mathrm{e}_{i j}
$$

where $\mathrm{Y}_{i j}=$ the dependent variable, $\mu=$ the overall mean, $\mathrm{B}_{i}=$ the random effect of $i$ th block, $\beta=$ the regression (covariate coefficient), $\mathrm{X}_{i j}=$ the covariate measurement, $\mathrm{TRT}_{j}=$ the fixed effect of the $j$ th treatment level of the dam, and $\mathrm{e}_{i j}=$ the residual error term. In this model, the random effect of calf within block subclass was used as the error term for the effect of treatment. Calf sex and twin versus single-born calf were run as covariates in the model. If $P>0.25$, the covariate(s) were removed from the model. Degrees of freedom were calculated using the Kenward-Roger approximation option of the MIXED procedure.
Blood metabolites, calf BW, skeletal measurements, and DMI were analyzed as repeated measures according to the following model:

$$
\begin{aligned}
\mathrm{Y}_{i j k l}= & \mu+\mathrm{B}_{i}+\mathrm{TRT}_{j}+\mathrm{W}_{k}+\beta \mathrm{X}_{i j} \\
& +\mathrm{TRT} \times \mathrm{W}_{j k}+\mathrm{e}_{i j k l},
\end{aligned}
$$

where $\mathrm{Y}_{i j k l}=$ the dependent variable, $\mu=$ the overall mean, $\mathrm{B}_{i}=$ the random effect of the $i$ th block, $\mathrm{TRT}_{j}=$ the fixed effect of the $j$ th treatment level of the dam, $\mathrm{W}_{k}=$ the fixed effect of the $k$ th week relative to birth, $\beta=$ the regression (covariate coefficient), $X_{i j}=$ the covariate measurement, TRT $\times \mathrm{W}_{j k}=$ the fixed interaction between the $j$ th treatment level and the $k$ th week, and $\mathrm{e}_{i j k l}=$ the residual error term. Calf sex and twin versus single-born calf were run as covariates in the model. If $P>0.25$, the covariate(s) were removed from the model. Calf DMI, free water intake, ADG, feed efficiency, and blood ketone concentration were modeled using a compound symmetry covariance spatial structure because it resulted in the smallest Bayesian information criterion. All other measurements were modeled using first-order autoregressive, because it resulted in the smallest Bayesian information criterion. Degrees of freedom were calculated using the Kenward-Roger approximation option of the MIXED procedure.

Planned contrasts were used to compare the linear, quadratic, and cubic effects of 3 incremental levels of NA versus control. Significance was declared at $P \leq$ 0.05 and trends at $0.05<P \leq 0.10$.

\section{RESULTS AND DISCUSSION}

The goal of this trial was to determine the effects of incremental levels of NA supplementation on the cow, colostrum quality, and performance of the calf. Much research has been done looking at the effects of NA in many situations (Niehoff et al., 2009a), but few studies have looked at the effects on colostrum quality and subsequent calf performance until weaning.

\section{Chemical Composition of Diets and Feed Ingredients}

Composition and nutrient analysis of the TMR are presented in Table 1. The diet was formulated to meet the nutrient requirements for close-up prepartum dairy cows (NRC, 2001). As previously mentioned, this study lasted for $13 \mathrm{mo}$; therefore, the diet analyses are shown with standard deviations, which indicate minimal changes in the diet throughout the trial. Analysis of orts indicated that minimal sorting of the diet occurred 
Table 3. Nutrient composition of orts

\begin{tabular}{lcccc}
\hline & \multicolumn{3}{c}{ Treatment $^{1}$} \\
\cline { 2 - 5 } Nutrient & CON & $16 \mathrm{NA}$ & $32 \mathrm{NA}$ & $48 \mathrm{NA}$ \\
\hline $\mathrm{CP}$ & $14.60 \pm 0$ & $14.60 \pm 0$ & $14.60 \pm 0$ & $14.50 \pm 0.3$ \\
$\mathrm{ADF}$ & $27.69 \pm 2.5$ & $25.97 \pm 1.7$ & $27.06 \pm 2.7$ & $26.02 \pm 2.1$ \\
$\mathrm{NDF}$ & $42.02 \pm 3.5$ & $39.52 \pm 2.5$ & $41.86 \pm 3.6$ & $40.32 \pm 2.7$ \\
$\mathrm{NFC}$ & $32.88 \pm 3.1$ & $34.19 \pm 2.3$ & $31.80 \pm 3.2$ & $33.69 \pm 2.1$ \\
Starch & $21.24 \pm 2.7$ & $21.72 \pm 2.7$ & $19.19 \pm 3.0$ & $22.01 \pm 3.3$ \\
Fat & $3.24 \pm 0.3$ & $3.32 \pm 0.4$ & $3.41 \pm 0.3$ & $3.62 \pm 3.3$ \\
$\mathrm{Ash}$ & $7.94 \pm 0.7$ & $8.22 \pm 0.5$ & $8.21 \pm 0.6$ & $7.77 \pm 0.5$ \\
$\mathrm{Ca}$ & $0.68 \pm 0.1$ & $0.74 \pm 0.1$ & $0.71 \pm 0.1$ & $0.68 \pm 0.1$ \\
$\mathrm{P}$ & $0.33 \pm 0.02$ & $0.35 \pm 0.03$ & $0.33 \pm 0.02$ & $0.33 \pm 0.02$ \\
$\mathrm{Mg}$ & $0.60 \pm 0.06$ & $0.63 \pm 0.05$ & $0.64 \pm 0.06$ & $0.59 \pm 0.04$ \\
$\mathrm{~K}$ & $1.52 \pm 0.4$ & $1.67 \pm 0.2$ & $1.65 \pm 0.2$ & $1.63 \pm 0.1$ \\
$\mathrm{Na}$ & $0.22 \pm 0.03$ & $0.23 \pm 0.03$ & $0.22 \pm 0.03$ & $0.21 \pm 0.03$ \\
$\mathrm{~S}$ & $0.45 \pm 0.04$ & $0.49 \pm 0.05$ & $0.48 \pm 0.05$ & $0.45 \pm 0.04$ \\
$\mathrm{Cl}$ & $0.78 \pm 0.08$ & $0.82 \pm 0.08$ & $0.84 \pm 0.1$ & $0.78 \pm 0.1$ \\
$\mathrm{Fe}(\mathrm{mg} / \mathrm{kg})$ & $259.33 \pm 82$ & $239.00 \pm 28$ & $276.44 \pm 104.7$ & $219.22 \pm 20.3$ \\
$\mathrm{Zn}(\mathrm{mg} / \mathrm{kg})$ & $67.56 \pm 4.1$ & $71.78 \pm 2.7$ & $71.00 \pm 6.5$ & $68.44 \pm 3.3$ \\
$\mathrm{Cu}(\mathrm{mg} / \mathrm{kg})$ & $15.22 \pm 1.6$ & $16.33 \pm 1.6$ & $16.22 \pm 1.8$ & $15.89 \pm 1.6$ \\
$\mathrm{Mn}(\mathrm{mg} / \mathrm{kg})$ & $61.56 \pm 8.9$ & $65.78 \pm 5.0$ & $67.44 \pm 9.4$ & $63.56 \pm 5.2$ \\
$\mathrm{DCAD}(\mathrm{mEq} / 100 \mathrm{~g})$ & $1.33 \pm 6.1$ & $-0.89 \pm 7.1$ & $-1.33 \pm 6.0$ & $1.22 \pm 5.9$ \\
\hline${ }^{1} \mathrm{CON}=0 \mathrm{~g} / \mathrm{d}$ nicotinic acid; $16 \mathrm{NA}=16 \mathrm{~g} / \mathrm{d}$ nicotinic acid; $32 \mathrm{NA}=32 \mathrm{~g} / \mathrm{d}$ nicotinic acid; $48 \mathrm{NA}=48 \mathrm{~g} / \mathrm{d}$ \\
nicotinic acid.
\end{tabular}

among treatments (Table 3). Composition and nutrient analysis of calf starter, starter orts, and MR are listed in Table 2.

\section{Cow Performance and Blood Metabolites}

Least squares means for DMI, BW, BW change, NEFA, BHB, and IgG concentrations in dams' blood are shown in Table 4. Dry matter intake decreased linearly with increasing NA level $(P=0.03)$, and a trend was observed for a treatment $\times$ week interaction $(P=$ $0.10)$, mainly due to the effect of week $(P<0.001)$ given that no differences were found between treatments at any week. Increased level of NA supplementation may have decreased diet palatability, causing a reduction in DMI. Previous DMI for cows fed $48 \mathrm{~g} / \mathrm{d}$ NA was 14.6 $\mathrm{kg} / \mathrm{d}$, which was not different from DMI of $16 \mathrm{~kg} / \mathrm{d}$ for control fed cows (Aragona et al., 2016). Campbell et al. (1994) reported no effect of $12 \mathrm{~g} / \mathrm{d}$ NA supplementation on DMI in late-lactation cows, which also agrees with work by Erickson et al. (1990, 1992). In contrast, Di Costanzo et al. (1997) found that $12 \mathrm{~g} / \mathrm{d}$ of NA increased DMI by $3.6 \%$ during heat stress. Effects of NA on DMI are variable, probably due to differences in diet formulation, milk performance, stage of lactation, as well as level and duration of NA supplementation. Average BW did not differ between NA treatments. Nicotinic acid had a negative quadratic effect $(P=$ $0.05)$ on BW change. All cows gained weight, which is expected due to fetal growth and colostrum production.
Reasons for this negative quadratic response in $\mathrm{BW}$ change could be related to the calculated ME yield of colostrum produced because it followed a similar trend, indicating a change in energy diverted into colostrum. Yield of colostral ME tended $(P=0.07)$ to respond cubically with increasing NA, decreasing from CON to $16 \mathrm{NA}$, increasing from $16 \mathrm{NA}$ to $32 \mathrm{NA}$, and decreasing from $32 \mathrm{NA}$ to $48 \mathrm{NA}$. However, the change from CON to $16 \mathrm{NA}$ was small and a tendency for ME to change in a negative quadratic effect, similar to the change in BW, was also observed. Nicotinic acid is a fundamental component of the biologically active coenzymes NAD and NADP, which both play important roles in many metabolic processes. Nicotinic acid supplementation up to $32 \mathrm{~g} / \mathrm{d}$ may have altered nutrient partitioning, leading to greater yield of fat, protein, and lactose in colostrum and thus the quadratic response in BW change.

No differences were observed for any blood parameters. Despite DMI decreasing linearly with increasing NA supplementation, no corresponding increase occurred for NEFA or ketones, which might be expected. A decrease in DMI, accompanied by the increase in energy demand during the prepartum period for colostrum and future milk production, can result in a state of negative energy balance. During this state, cows will mobilize adipose tissue to help meet energy needs, leading to an increase in NEFA. If mobilization of adipose occurs rapidly, $\beta$-oxidation in the liver will not be able to keep up, causing an increase in ketone production, such as BHB, which can lead to ketosis. Supplemental 
Table 4. Dry matter intake, BW, and blood metabolite data for cows supplemented 0, 16, 32, or $48 \mathrm{~g} / \mathrm{d}$ nicotinic acid prepartum

\begin{tabular}{|c|c|c|c|c|c|c|c|c|c|}
\hline Item & \multicolumn{4}{|c|}{ Treatment $^{1}$} & SEM & \multicolumn{4}{|c|}{$P$-value ${ }^{2}$} \\
\hline DMI $(\mathrm{kg} / \mathrm{d})$ & 16.08 & 16.27 & 15.44 & 14.78 & 0.47 & 0.03 & 0.36 & 0.62 & 0.10 \\
\hline BW change (kg) & 7.15 & 4.06 & 6.00 & 10.70 & 2.01 & 0.14 & 0.05 & 0.66 & 0.43 \\
\hline $\mathrm{NEFA}^{3}(\mathrm{mEq} / \mathrm{L})$ & 230.49 & 217.63 & 247.99 & 239.71 & 17.10 & 0.45 & 0.89 & 0.54 & 0.13 \\
\hline Ketones $(\mathrm{mmol} / \mathrm{L})$ & 0.72 & 0.68 & 0.71 & 0.73 & 0.04 & 0.79 & 0.50 & 0.83 & 0.98 \\
\hline
\end{tabular}

${ }^{1} \mathrm{CON}=0 \mathrm{~g} / \mathrm{d}$ nicotinic acid; $16 \mathrm{NA}=16 \mathrm{~g} / \mathrm{d}$ nicotinic acid; $32 \mathrm{NA}=32 \mathrm{~g} / \mathrm{d}$ nicotinic acid; $48 \mathrm{NA}=48 \mathrm{~g} / \mathrm{d}$ nicotinic acid.

${ }^{2}$ Orthogonal polynomials were used to test linear (L), quadratic (Q), and cubic $(\mathrm{C})$ effects. Trt = treatment.

${ }^{3} \mathrm{NEFA}=$ nonesterified fatty acids.

NA has been shown to alter lipolysis in some studies (Fronk and Schultz, 1979; Erickson et al., 1990; Pires et al., 2007) but not in others (Niehoff et al., 2009b). At pharmacological levels, NA can inhibit lipolysis via the G protein-coupled receptor 109A (Tunaru et al., 2003; Benyó et al., 2006). Inhibition of this receptor reduces activity of adenylyl cyclase, inhibiting production of cyclic (c)AMP (Harvey and Ferrier, 2011). Normally, high levels of cAMP lead to activation of protein kinase A, which phosphorylates hormone-sensitive lipase, activating it to break down triglycerides from adipose tissue into NEFA. Therefore, preventing a rise in cAMP levels will reduce the release of NEFA into the bloodstream, potentially reducing the incidence of ketosis. Despite the decrease in DMI in this study, no increase was observed in NEFA or ketones, indicating that supplemental NA may have altered metabolism and lipolysis.

\section{Urinary Metabolites}

Least squares means for urine $\mathrm{pH}$ and volume, and urine metabolites are shown in Table 5. No treatment $\times$ week effects were observed, but an increasing NA level was associated with a trend for a negative quadratic response in urine $\mathrm{pH}(P=0.08)$. Supplementing anionic salts in the prepartum period is common to aid in preventing metabolic disorders, such as periparturient hypocalcemia, around calving. Leading up to parturition, the demand for Ca for colostrum and milk production increases dramatically. A mild metabolic acidosis is induced through use of anionic salts, which enhances intestinal absorption and bone resorption of $\mathrm{Ca}$ and decreases bone accretion and renal reabsorption of Ca to increase plasma Ca concentrations. Urine $\mathrm{pH}$ values are close to the suggested range of 6.2 to 6.8 to increase mobilization of bone $\mathrm{Ca}^{2+}$ (Riond, 2001). The enzyme NAD glycohydrolase catalyzes transfer of ADP-ribose, which is a second messenger involved in Ca homeostasis (Kim at al., 1994). The negative quadratic effect observed with NA supplementation may be due to altered Ca homeostasis, which would affect blood and therefore urine $\mathrm{pH}$. No differences were observed for urine volume, $\mathrm{N}$ excretion, uric acid, or urea $\mathrm{N}$ in cows that were supplemented with $\mathrm{NA}$. Allantoin and total PD increased linearly $(P=0.02)$ with increasing NA level. Urinary excretion of PD has been proposed as a metabolic marker of microbial synthesis (Topps and Elliott, 1965). More recently developed methods assume that nucleic acids flowing through the duodenum are of microbial origin. Purine nucleotides are digested in the intestine, and absorbed adenine and guanine are catabolized and proportionally excreted in urine as allantoin and uric acid (Valadares et al., 1999). Supplemental NA increased ruminal protozoa in many cases (Dennis et al., 1982; Erickson et al., 1990; Doreau and Ottou, 1996; Aschemann et al., 2012), most likely because protozoa are unable to synthesize niacin and rely on niacin provided from feed or synthesized by bacteria (Doreau and Ottou, 1996). In a study evaluating NA uptake from the rumen, Erickson et al. (1991) found that NA was not absorbed across the rumen wall. Therefore, NA would be available to the rumen microbiota or to the small intestine. Nicotinic acid was shown to increase entodinia, which engulf starch, enhancing the rumen environment, which in turn leads to increased proliferation of microbes (Erickson et al., 1990). Increased microbial proliferation would result in greater MCP production, which provides the majority of absorbable amino acids to the small intestine of the cow. Therefore, an increase in MCP could lead to an increase in AA absorption in the cow and increased PD excretion in urine, an internal metabolic marker of microbial production, which was observed in this study.

\section{Colostrum Composition}

Least squares means for colostrum yield and composition are in Table 6. No differences were observed in yield of colostrum with increasing NA level. The concentration of $\operatorname{IgG}$ in colostrum increased linearly $(P=$ 
Table 5. Urinary $\mathrm{pH}$, volume, and excretion of allantoin, uric acid, and urea $\mathrm{N}$ for cows supplemented $0,16,32$, or $48 \mathrm{~g} / \mathrm{d}$ nicotinic acid prepartum

\begin{tabular}{|c|c|c|c|c|c|c|c|c|}
\hline \multirow[b]{2}{*}{ Item } & \multicolumn{4}{|c|}{ Treatment $^{1}$} & \multirow[b]{2}{*}{ SEM } & \multicolumn{3}{|c|}{$P$-value ${ }^{2}$} \\
\hline & $\mathrm{CON}$ & $16 \mathrm{NA}$ & $32 \mathrm{NA}$ & $48 \mathrm{NA}$ & & $\mathrm{L}$ & $\mathrm{Q}$ & $\mathrm{C}$ \\
\hline Urine $\mathrm{pH}$ & 6.20 & 5.98 & 6.12 & 6.23 & $1.45 \times 10^{-7}$ & 0.45 & 0.08 & 0.21 \\
\hline \multicolumn{9}{|l|}{ Urinary metabolites } \\
\hline $\mathrm{N}$ excretion $(\mathrm{g} / \mathrm{d})$ & 175.59 & 173.44 & 164.96 & 169.42 & 7.71 & 0.41 & 0.64 & 0.87 \\
\hline Allantoin $(\mathrm{mmol} / \mathrm{d})$ & 101.55 & 95.48 & 118.45 & 133.31 & 13.57 & 0.02 & 0.33 & 0.69 \\
\hline Urea N (g/d) & 71.12 & 86.84 & 74.15 & 81.74 & 7.75 & 0.54 & 0.56 & 0.11 \\
\hline
\end{tabular}

${ }^{1} \mathrm{CON}=0 \mathrm{~g} / \mathrm{d}$ nicotinic acid; $16 \mathrm{NA}=16 \mathrm{~g} / \mathrm{d}$ nicotinic acid; $32 \mathrm{NA}=32 \mathrm{~g} / \mathrm{d}$ nicotinic acid; $48 \mathrm{NA}=48 \mathrm{~g} / \mathrm{d}$ nicotinic acid.

${ }^{2}$ Orthogonal polynomials were used to test linear (L), quadratic (Q), and cubic (C) effects.

${ }^{3}$ Urinary volume was estimated from the urinary concentration of creatinine, assuming a constant creatinine excretion rate of $25.23 \mathrm{mg} / \mathrm{kg}$ of BW for dry cows (Valadares et al., 1997, 1999).

${ }^{4}$ Total purine derivatives (PD) were calculated by adding allantoin and uric acid excretion.

0.02) with increasing NA level, which agrees with previous research in which $48 \mathrm{~g} / \mathrm{d}$ NA increased colostral IgG concentration from 73.8 to $86.8 \mathrm{~g} / \mathrm{L}$ (Aragona et al., 2016). Immunoglobulins consist of 2 heavy and 2 light polypeptide chains that contain hundreds of AA (Akers 2002). The large increase in colostral IgG concentration can be attributed to an increase in microbial protein production, as indicated by the increase in urinary excretion of PD observed in this study. Although no literature directly compares the relationship between MCP production and colostral protein, specifically IgG, a meta-analysis assessing the relationship between NAN flow in the omasum and milk protein yield found that as NAN flow increases, milk protein yield increases (Huhtanen et al., 2010). This finding indicates that as $\mathrm{MCP}$ production increases and MCP leaves the ru- men, it is absorbed as free AA in the small intestine, providing greater AA for milk protein production. Therefore, additional substrate (AA) for incorporation into immunoglobulins would, theoretically, increase IgG production and concentration in colostrum, which was observed in this case. Positive effects of NA on milk protein production have been observed by others (Riddell et al., 1981; Erickson et al., 1992; Karkoodi and Tamizrad, 2009; Niehoff et al., 2009b) and were attributed to greater microbial protein production (Riddell et al., 1981). Prepartum NA supplementation may possibly alter metabolism of nutrients, resulting in greater nutrient partitioning into colostrum. Nicotinic acid was associated with a positive quadratic response $(P=0.03)$ in yield of $\mathrm{IgG}$. In addition, increasing NA level was associated with a linear increase $(P=0.05)$ in

Table 6. Colostrum yield and composition for cows supplemented $0,16,32$, or $48 \mathrm{~g} / \mathrm{d}$ nicotinic acid prepartum

\begin{tabular}{|c|c|c|c|c|c|c|c|c|}
\hline Item & \multicolumn{4}{|c|}{ Treatment $^{1}$} & SEM & \multicolumn{3}{|c|}{$P$-value ${ }^{2}$} \\
\hline Colostrum yield (L) & 11.38 & 10.83 & 12.25 & 8.53 & 1.54 & 0.29 & 0.30 & 0.16 \\
\hline IgG yield (g) & 548.86 & 768.38 & 807.54 & 577.74 & 98.97 & 0.77 & 0.03 & 0.96 \\
\hline Fat $(\%)$ & 4.51 & 7.30 & 6.90 & 6.10 & 0.90 & 0.28 & 0.05 & 0.28 \\
\hline Fat vield $(\mathrm{kg})$ & 0.63 & 0.85 & 0.92 & 0.48 & 0.16 & 0.60 & 0.05 & 0.51 \\
\hline Ash yield (kg) & 0.12 & 0.14 & 0.15 & 0.10 & 0.02 & 0.49 & 0.05 & 0.28 \\
\hline Solids (\%) & 23.19 & 26.41 & 25.83 & 26.70 & 1.08 & 0.05 & 0.29 & 0.07 \\
\hline Solids yield $(\mathrm{kg})$ & 2.61 & 3.09 & 3.17 & 2.06 & 0.39 & 0.37 & 0.05 & 0.65 \\
\hline Lactose (\%) & 3.25 & 2.87 & 2.99 & 3.22 & 0.23 & 0.98 & 0.20 & 0.75 \\
\hline Lactose yield ( $\mathrm{kg}$ ) & 0.37 & 0.34 & 0.36 & 0.25 & 0.05 & 0.13 & 0.35 & 0.15 \\
\hline $\mathrm{ME}^{3}(\mathrm{MJ} / \mathrm{kg})$ & 22.89 & 24.07 & 23.93 & 23.29 & 0.58 & 0.67 & 0.11 & 0.62 \\
\hline
\end{tabular}

${ }^{1} \mathrm{CON}=0 \mathrm{~g} / \mathrm{d}$ nicotinic acid; $16 \mathrm{NA}=16 \mathrm{~g} / \mathrm{d}$ nicotinic acid; $32 \mathrm{NA}=32 \mathrm{~g} / \mathrm{d}$ nicotinic acid; $48 \mathrm{NA}=48 \mathrm{~g} / \mathrm{d}$ nicotinic acid.

${ }^{2}$ Orthogonal polynomials were used to test linear $(\mathrm{L})$, quadratic $(\mathrm{Q})$, and cubic $(\mathrm{C})$ effects.

${ }^{3} \mathrm{ME}$ of colostrum was estimated based on the ME calculation of milk (NRC, 2001). 
protein and solids content, which can be attributed to the large increase in IgG concentration.

Ash content increased linearly $(P<0.01)$ with increasing NA level, and a positive quadratic response $(P=0.05)$ in ash yield occurred with NA. Nicotinic acid supplementation has been shown to cause vasodilation through activation of the $\mathrm{G}$ protein-coupled receptor 109A (Tunaru et al., 2003; Benyó et al., 2006), which could potentially lead to an increase in blood flow to the mammary gland leading up to parturition. As cows approach parturition, plasma $\mathrm{Ca}$ and inorganic $\mathrm{P}$ decrease because of colostrogenesis (Horst, 1986; Littledike and Goff, 1987). Therefore, by supplementing NA during colostrogenesis, increased blood flow to the mammary gland may have resulted in the transfer of greater minerals, resulting in greater colostral ash concentration with increasing NA supplementation.

A positive quadratic response $(P=0.05)$ in fat content and fat yield occurred with NA. Improvements in milk fat and FCM have been observed by others when rumen-degradable NA was fed (Belibasakis and Tsirgogianni, 1996; Drackley et al., 1998; Schwab et al., 2005; Karkoodi and Tamizrad, 2009), but not when rumen- protected NA products were fed (Zimbelman et al., 2010; Yuan et al., 2011, 2012). Reasons for increased milk fat may be attributed to increased NADP availability. Specifically, NADP is involved in fatty acid synthesis. Increasing available NADP, by supplementing NA, may have resulted in the increased colostral fat in this study. However, fat content in colostrum responded in a positive quadratic manner, indicating that greater levels of NA may negatively alter metabolic processes in some way. With supplementation of such levels, the ratio of $\mathrm{NAD} / \mathrm{NADH}$ or $\mathrm{NADP} / \mathrm{NADPH}$, the oxidized and reduced forms of the coenzymes, may have been altered and affected fatty acid synthesis. Another possibility is that an increase in the milk fat precursor, acetate, from greater NDF digestibility, could have resulted in greater colostral fat (Belibasakis and Tsirgogianni, 1996). The proportion of oleic acid in milk was increased with NA supplementation in a previous study (Niehoff et al., 2009b). Zimmerman et al. (1992) found that total long-chain fatty acids were decreased, but short-chain fatty acids were increased, when NA was supplemented to a high-protein diet, which would follow the theory of increased acetate in the rumen, as

Table 7. Intake and performance of calves born from dams supplemented $0,16,32$, or $48 \mathrm{~g} / \mathrm{d}$ nicotinic acid prepartum

\begin{tabular}{|c|c|c|c|c|c|c|c|c|c|}
\hline \multirow[b]{2}{*}{ Item } & \multicolumn{4}{|c|}{ Treatment $^{1}$} & \multirow[b]{2}{*}{ SEM } & \multicolumn{4}{|c|}{$P$-value ${ }^{2}$} \\
\hline & $\mathrm{CON}$ & $16 \mathrm{NA}$ & $32 \mathrm{NA}$ & $48 \mathrm{NA}$ & & $\mathrm{L}$ & Q & $\mathrm{C}$ & Trt $\times$ wk \\
\hline $24 \mathrm{~h} \mathrm{IgG} \mathrm{(g/L)}$ & 28.20 & 32.41 & 31.13 & 30.08 & 3.24 & 0.76 & 0.40 & 0.61 & - \\
\hline $\operatorname{AEA}^{3}(\%)$ & 49.02 & 51.18 & 47.81 & 46.90 & 4.73 & 0.62 & 0.71 & 0.88 & - \\
\hline MEi colostrum ${ }^{4}$ (MJ) & 84.31 & 91.00 & 91.48 & 86.54 & 3.30 & 0.63 & 0.09 & 0.79 & - \\
\hline Starter intake $(\mathrm{g} / \mathrm{d})$ & 699.69 & 642.13 & 656.12 & 546.05 & 66.52 & 0.13 & 0.67 & 0.19 & $<0.01$ \\
\hline MR intake $(\mathrm{g} / \mathrm{d})$ & 449.0 & 449.0 & 449.0 & 449.0 & - & - & - & - & - \\
\hline Free water intake $(\mathrm{kg} / \mathrm{d})$ & 1.30 & 1.05 & 1.16 & 1.19 & 0.22 & 0.81 & 0.49 & 0.60 & $<0.01$ \\
\hline Initial BW (kg) & 45.15 & 44.81 & 44.72 & 44.26 & 1.70 & 0.72 & 0.97 & 0.81 & - \\
\hline Final BW (kg) & 65.24 & 63.55 & 64.31 & 61.81 & 2.82 & 0.41 & 0.88 & 0.43 & - \\
\hline $\mathrm{ADG}(\mathrm{g} / \mathrm{d})$ & 479.86 & 454.55 & 529.45 & 368.17 & 37.78 & 0.12 & 0.07 & 0.01 & $<0.01$ \\
\hline $\mathrm{ADG} / \mathrm{DMI}$ & 0.36 & 0.36 & 0.50 & 0.34 & 0.04 & 0.63 & 0.03 & 0.03 & $<0.01$ \\
\hline Initial withers height $(\mathrm{cm})$ & 80.62 & 79.43 & 80.23 & 80.03 & 0.85 & 0.80 & 0.54 & 0.40 & - \\
\hline Withers height gain $(\mathrm{cm})$ & 5.95 & 6.61 & 6.66 & 6.76 & 0.49 & 0.28 & 0.54 & 0.42 & - \\
\hline Final withers height $(\mathrm{cm})$ & 87.49 & 86.14 & 88.08 & 87.37 & 0.83 & 0.64 & 0.67 & 0.19 & - \\
\hline Initial hip height $(\mathrm{cm})$ & 83.25 & 82.68 & 84.13 & 83.30 & 1.03 & 0.73 & 0.89 & 0.48 & - \\
\hline Hip height gain $(\mathrm{cm})$ & 5.94 & 6.45 & 6.71 & 7.10 & 0.57 & 0.14 & 0.92 & 0.41 & - \\
\hline Final hip height (cm) & 90.91 & 89.56 & 91.50 & 91.00 & 0.78 & 0.48 & 0.56 & 0.21 & - \\
\hline Initial hip width (cm) & 21.80 & 21.84 & 21.87 & 22.09 & 0.38 & 0.58 & 0.80 & 0.71 & - \\
\hline Hip width gain $(\mathrm{cm})$ & 2.08 & 1.24 & 2.34 & 2.02 & 0.16 & 0.20 & 0.14 & $<0.01$ & - \\
\hline Final hip width (cm) & 24.28 & 23.73 & 24.21 & 24.22 & 0.36 & 0.84 & 0.41 & 0.43 & - \\
\hline Initial body length $(\mathrm{cm})$ & 66.69 & 66.65 & 66.74 & 67.06 & 0.89 & 0.76 & 0.84 & 0.88 & - \\
\hline Body length gain $(\mathrm{cm})$ & 9.65 & 8.18 & 9.75 & 7.51 & 0.73 & 0.11 & 0.76 & 0.01 & - \\
\hline Final body length (cm) & 76.75 & 75.05 & 77.54 & 75.11 & 0.97 & 0.54 & 0.69 & 0.03 & - \\
\hline Initial girth $(\mathrm{cm})$ & 83.24 & 82.28 & 82.56 & 82.63 & 1.25 & 0.78 & 0.66 & 0.71 & - \\
\hline Girth gain $(\mathrm{cm})$ & 9.38 & 9.57 & 10.45 & 8.94 & 0.75 & 0.89 & 0.25 & 0.35 & - \\
\hline Final girth $(\mathrm{cm})$ & 93.94 & 92.53 & 93.95 & 91.89 & 1.49 & 0.44 & 0.81 & 0.22 & - \\
\hline Ketones $(\mathrm{mmol} / \mathrm{L})$ & 0.25 & 0.28 & 0.27 & 0.24 & 0.01 & 0.33 & 0.03 & 0.96 & - \\
\hline
\end{tabular}

${ }^{1}$ Treatments fed to dams prepartum; $\mathrm{CON}=0 \mathrm{~g} / \mathrm{d}$ nicotinic acid; $16 \mathrm{NA}=16 \mathrm{~g} / \mathrm{d}$ nicotinic acid; $32 \mathrm{NA}=32 \mathrm{~g} / \mathrm{d}$ nicotinic acid; $48 \mathrm{NA}=48$ $\mathrm{g} / \mathrm{d}$ nicotinic acid.

${ }^{2}$ Orthogonal polynomials were used to test linear $(\mathrm{L})$, quadratic $(\mathrm{Q})$, and cubic $(\mathrm{C})$ effects. Trt $=$ treatment.

${ }^{3}$ Apparent efficiency of absorption $(\mathrm{AEA}):\{[24 \mathrm{~h}$ plasma $\operatorname{IgG}(\mathrm{g} / \mathrm{L}) \times \mathrm{BW}(\mathrm{kg}) \times 0.09] / \mathrm{IgG}$ intake $(\mathrm{g} / \mathrm{L})\} \times 100($ Quigley et al., 1998$)$.

${ }^{4} \mathrm{MEi}$ colostrum $=\mathrm{ME}$ intake from colostrum, estimated based on the ME calculation for milk (NRC, 2001). 
acetate is the precursor for short- and medium-chain fatty acids in the mammary gland (Horner et al., 1988). An increase in milk fat was not observed in many cases when rumen-protected NA forms were supplemented (Zimbelman et al., 2010; Yuan et al., 2011), which may indicate that the increase in fat is due to changes in ruminal fermentation. Colostral ME was estimated based on the ME calculation of milk (NRC, 2001). Colostral ME concentration approached a tendency $(P$ $=0.11$ ) for a positive quadratic response. The yield of ME colostrum tended $(P=0.07)$ to change cubically, decreasing from $\mathrm{CON}$ to $16 \mathrm{NA}$, increasing from 16NA to $32 \mathrm{NA}$, and decreasing from $32 \mathrm{NA}$ to $48 \mathrm{NA}$, indicating NA altered metabolism, nutrient partitioning, or both. Reasons for this cubic response are unclear, but it follows the same trend as colostrum yield.

\section{Calf Intake, Growth, and Blood Metabolites}

Least squares means for starter intake, MR intake, ADG, skeletal measurements, and blood metabolites for calves are in Table 7. Concentrations of 24-h IgG and apparent efficiency of absorption were not different among calves at $24 \mathrm{~h}$ of age, which agrees with previous research (Aragona et al., 2016).

No differences were observed in calf starter intake as NA supplementation of dams increased (Table 7; Figure 1). A treatment $\times$ week effect $(P<0.001)$ was observed for calf starter intake, but no differences were found between treatments. Calf starter intake increased with age, which most likely contributed to the observed treatment $\times$ week effect. Average daily gain changed cubically $(P=0.01)$ with NA, decreasing from $\mathrm{CON}$ to $16 \mathrm{NA}$, increasing from $16 \mathrm{NA}$ to $32 \mathrm{NA}$, and decreasing from $32 \mathrm{NA}$ to $48 \mathrm{NA}$ (Table 7; Figure 2). No differences were observed in free water intake, but intake increased with age (Table 7; Figure 3). Feed efficiency (ADG/DMI) changed quadratically $(P=0.03)$ with $\mathrm{NA}$, increasing from $\mathrm{CON}$ to $32 \mathrm{NA}$, then decreasing from 32NA to 48NA (Table 7; Figure 4). A treatment $\times$ week effect was found for ADG/DMI, with calves fed $32 \mathrm{~g} / \mathrm{d}$ having greater feed efficiency during wk 2 and 3 of life. A treatment $\times$ week effect was not observed during wk 4 to 6 , when starter intake increases

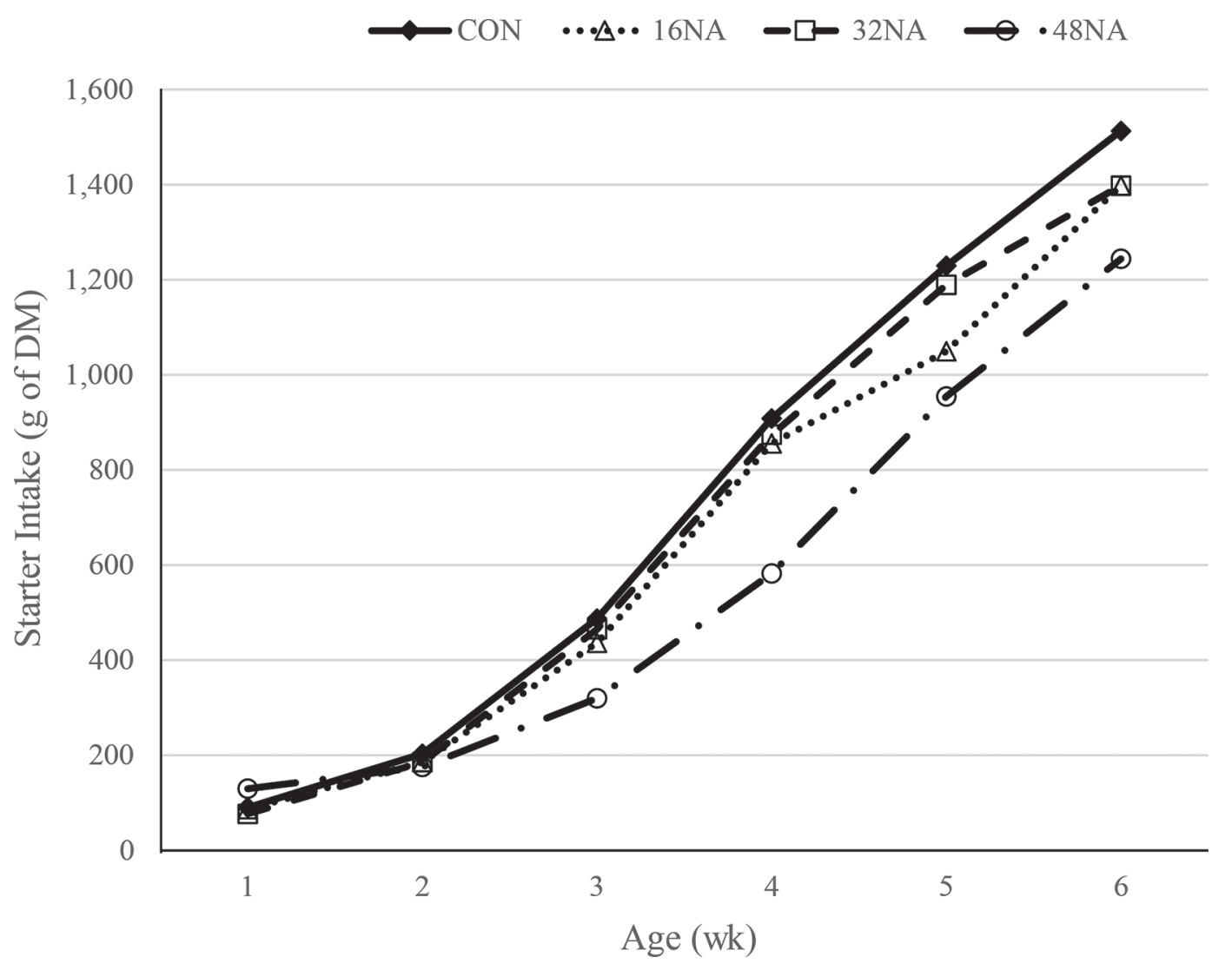

Figure 1. Starter intake of calves born from dams supplemented with 0, 16, 32, or $48 \mathrm{~g} / \mathrm{d}$ nicotinic acid (CON, 16NA, 32NA, and 48NA, respectively) in the prepartum period. 
drastically. During the first 3 wk of life, nutrients are mainly provided by $\mathrm{MR}$, as calf starter intake is low and the rumen is still small and undeveloped. Intestinal development in utero may have been affected by the additional MCP that was provided to the dam due to NA supplementation, as indicated by increased PD. Altering the supply of dietary protein during gestation has been shown to affect the calf's ability to absorb nutrients from colostrum (Burton et al., 1984; Hough et al., 1990; Toghyani and Moharrery, 2015), which authors attributed to changes in the morphological development of intestinal enterocytes, as observed in rats (Loh et al., 1971). This potential change in intestinal morphology may have affected the ability of the calf to absorb nutrients from MR later in life. Another possibility is that the observed tendency $(P=0.07)$ for a positive quadratic response in colostrum ME intake may explain the observed positive quadratic response in feed efficiency, as calves consuming colostrum from dams fed 32NA received greater levels of ME. Hip width gain, body length gain, and final body length changed cubically with NA, decreasing from CON to $16 \mathrm{NA}$, increasing from 16NA to $32 \mathrm{NA}$, and decreasing from $32 \mathrm{NA}$ to $48 \mathrm{NA}$. In each case, calves born from cows fed 32NA had the greatest values. The reason for this cubic response is unclear. This response may be related to the response in urinary PD observed from NA supplementation in dams. Although microbial production of niacin is estimated to be $1,804 \mathrm{mg} / \mathrm{d}$, this estimate is based on work with steers (NRC, 2001). Requirements for niacin have not been determined experimentally in lactating or pregnant cows but are based on work with lactating sows (NRC, 1998); therefore, they do not consider microbial requirements, impacts of ruminal fermentation, or the developing fetus. Based on this information, in conjunction with the observed results, assumptions about niacin requirements or its production may be incorrect and further study is needed. Therefore, providing some NA (i.e., $16 \mathrm{~g} / \mathrm{d}$ ) may have resulted in decreased bacterial production of NA, as bacteria seem to rely on preformed NA when supplemented in the diet rather than their own production, which is an energy-demanding process (Abdouli and Schaefer, 1986). This situation could lead to decreased microbial proliferation and therefore decreased MCP, with decreased AA reaching the small intestine of the cow, which may have negatively affected fetal development. Although urinary excretion of allantoin and total PD increased linearly, 16NA was numerically lower than CON, which supports this theory. Ketone concentration changed quadratically, increasing from CON to $32 \mathrm{NA}$ and decreasing from $32 \mathrm{NA}$ to $48 \mathrm{NA}$,

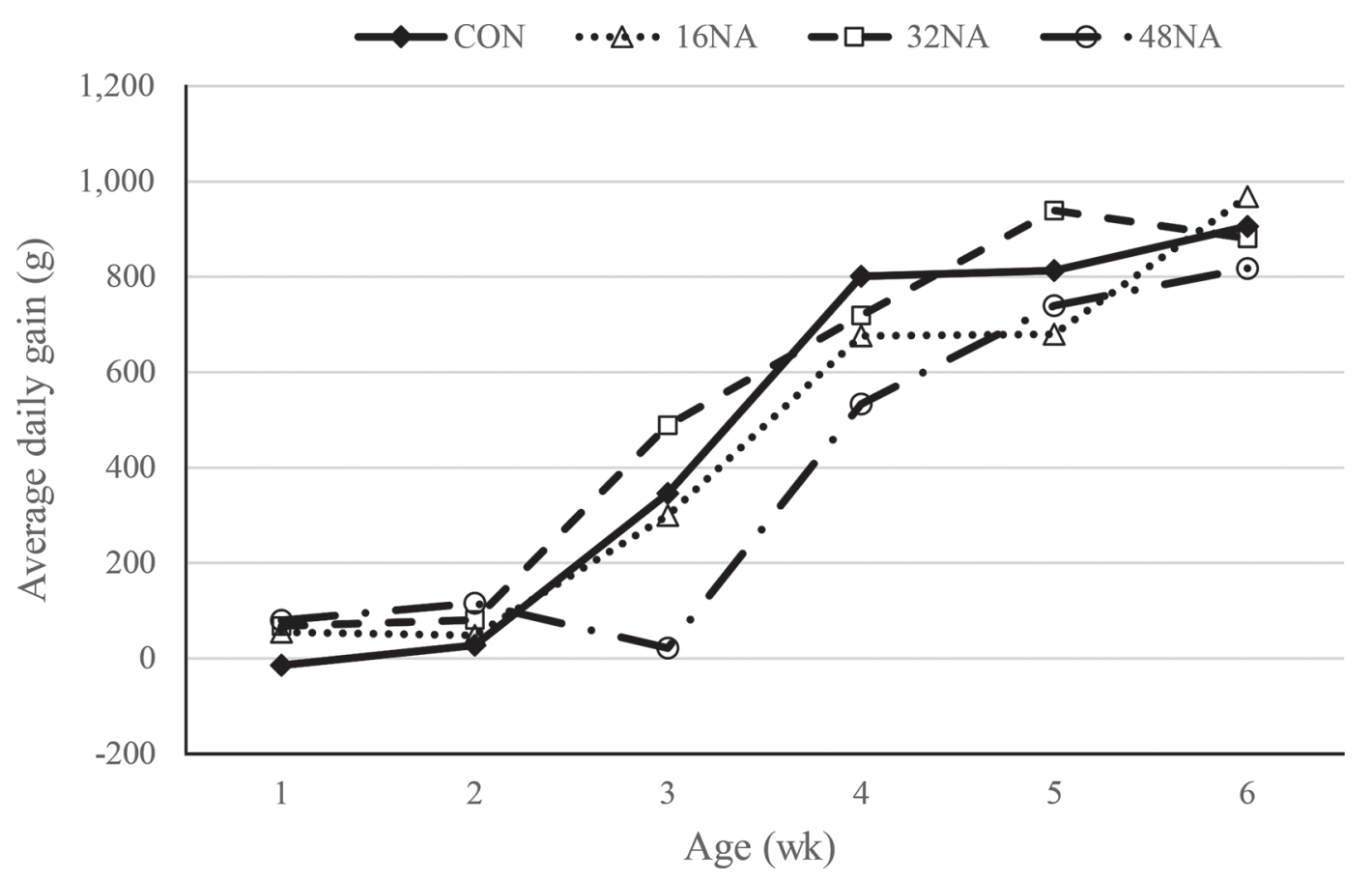

Figure 2. Average daily gain for calves born from dams supplemented with 0, 16, 32, or $48 \mathrm{~g} / \mathrm{d}$ nicotinic acid (CON, 16NA, 32NA, and 48NA, respectively) in the prepartum period. In wk 3 , ADG was greater $(P<0.05)$ for calves born from dams fed CON, 16NA, or 32NA versus $48 \mathrm{NA}$. In wk $4, \mathrm{ADG}$ was greater $(P<0.05)$ for calves born from dams fed CON versus 48NA. In wk 5 , ADG was greater $(P<0.05)$ for calves born from dams fed $16 \mathrm{NA}$ versus $48 \mathrm{NA}$. In wk 6 , ADG was greater $(P<0.05)$ for calves born from dams fed $16 \mathrm{NA}$ versus $48 \mathrm{NA}$. 


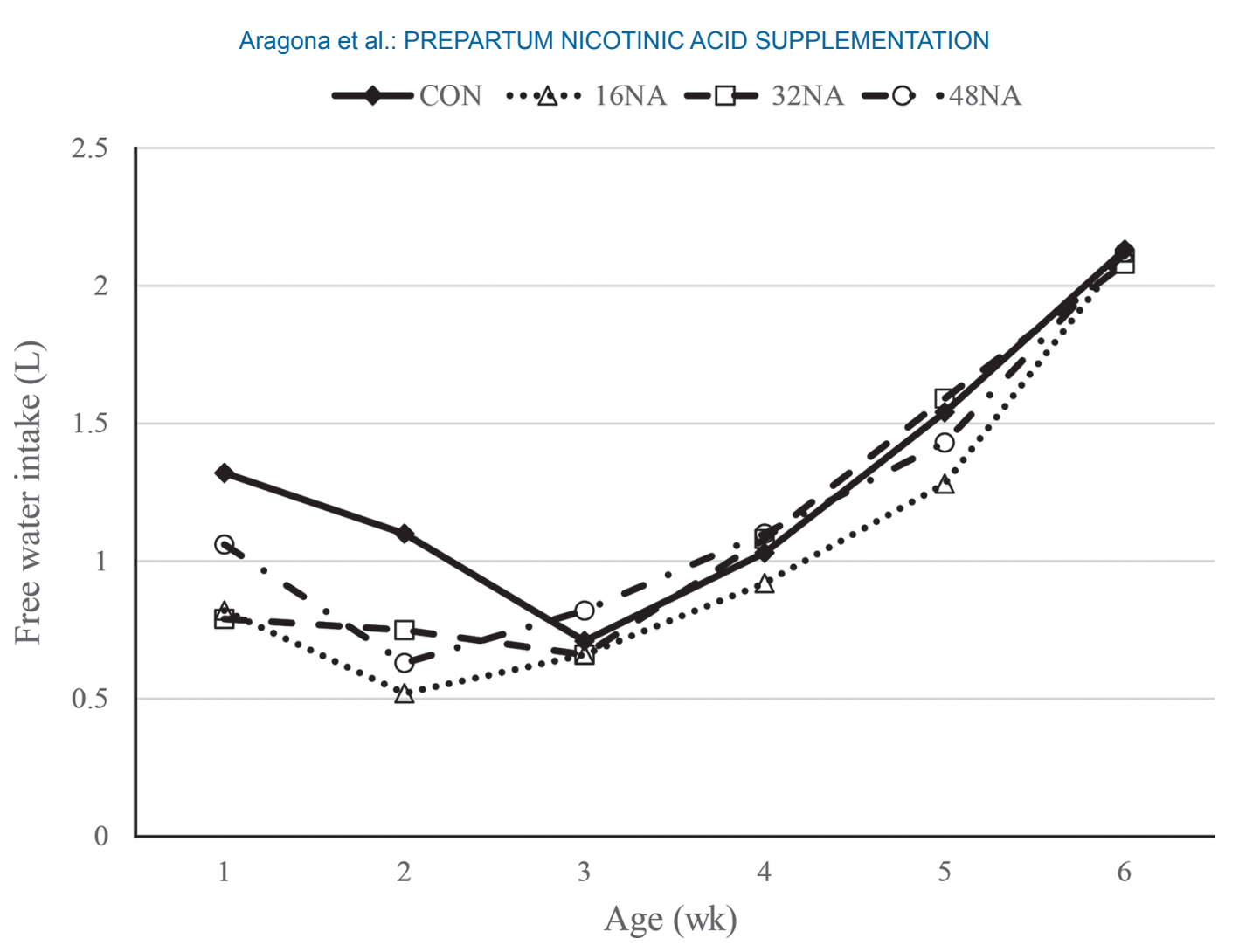

Figure 3. Free water intake of calves born from dams supplemented with 0, 16, 32, or $48 \mathrm{~g} / \mathrm{d}$ nicotinic acid (CON, 16NA, 32NA, and 48NA, respectively) in the prepartum period.

which indicates that rumen development may have been positively affected up to $32 \mathrm{NA}$.

Supplemental NA to prepartum cows increased quality of colostrum produced, most likely a result of increased microbial protein production as indicated by increased excretion of purine derivates. The increased MCP supplied to the dam during pregnancy may have also affected the intestinal development of the fetus. Increased intestinal development could lead to better utilization of MR nutrients during the first few weeks of life, resulting in the observed increases in feed efficiency and skeletal measurements. The increased feed efficiency and skeletal gains in calves born from dams fed NA may also have been due to increased provision of nutrients from colostrum on d 1 of life. Providing greater-quality colostrum ensures proper health, growth, and development in early life and is critical to subsequent health and growth.

\section{CONCLUSIONS}

Results of this study indicate that supplemental NA in the prepartum period leads to an increase in allantoin and total PD, with 48NA resulting in the greatest colostral IgG concentration, supporting our hypothesis.
Supplemental NA also resulted in increases in other colostral nutrients. Positive quadratic responses in other colostral nutrients and ME concentration may be the reason increased feed efficiency and skeletal growth were observed in calves born from cows receiving 32NA prepartum, as consumption of high-quality colostrum is arguably the most important influence on calf immunity, as well as future growth and performance. With more than $60 \%$ of colostrum in the United States being below industry standards and colostrum quality issues existing in other parts of the world, these results will have a profound impact on management strategies in pre-fresh cow nutrition to improve colostrum quality, while also increasing calf feed efficiency and growth.

\section{ACKNOWLEDGMENTS}

This research was funded by DSM Nutritional Products. We thank Mark Hill and colleagues at Provimi (Brookville, $\mathrm{OH}$ ) for their support through donation of milk replacer and calf starter used in this experiment and the Fairchild Dairy Teaching and Research Center staff for their assistance. Partial funding was provided by the New Hampshire Agricultural Experiment Station. This is scientific contribution number 2820. This 


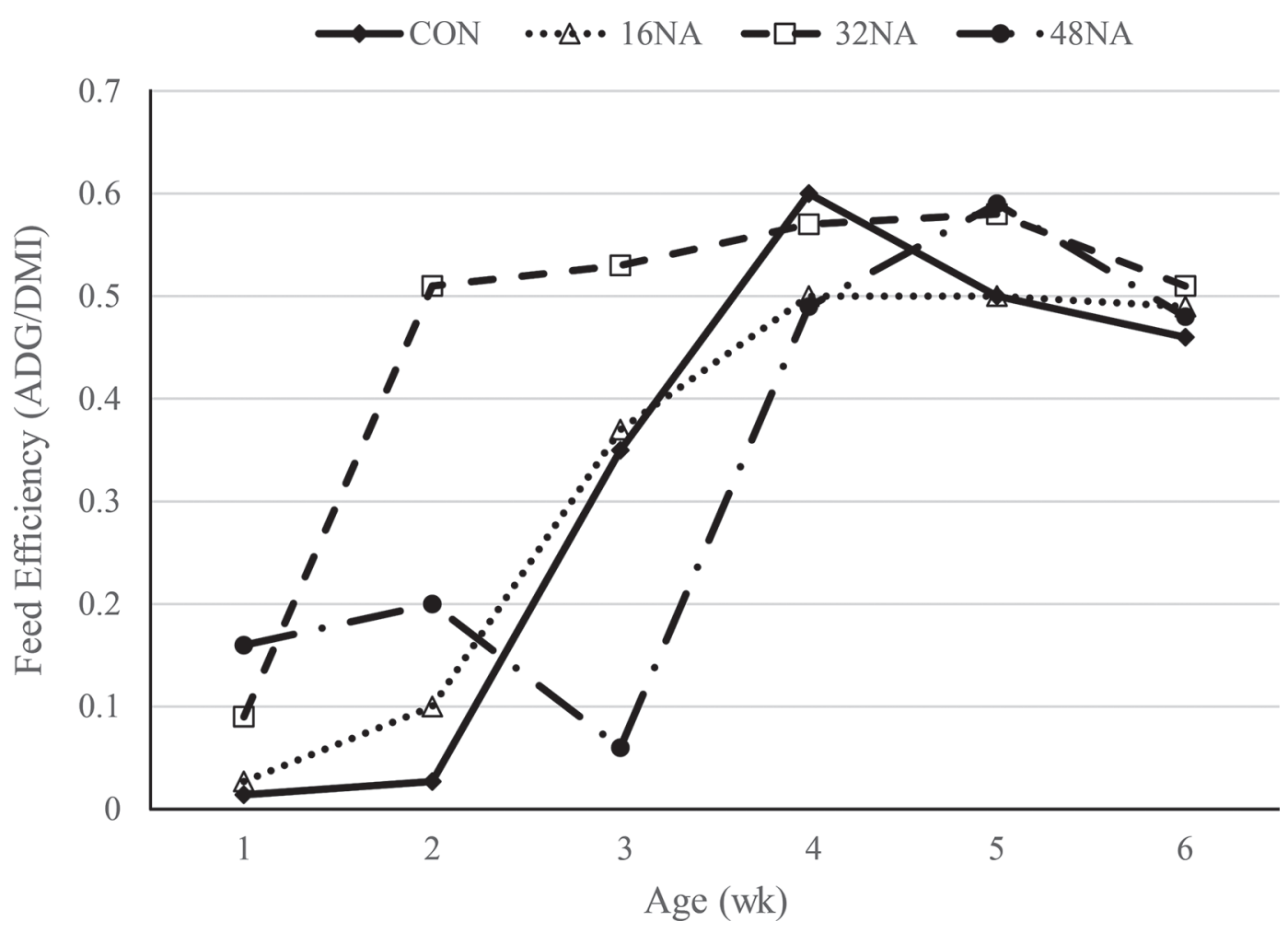

Figure 4. Feed efficiency of calves born from dams supplemented with $0,16,32$, or $48 \mathrm{~g} / \mathrm{d}$ of nicotinic acid (CON, 16NA, 32NA, and 48NA, respectively) in the prepartum period. In wk 2 and 3 , feed efficiency was greater $(P<0.05)$ for calves born from dams fed 32NA versus CON, $16 \mathrm{NA}$, and 48NA. In wk 3 , feed efficiency was greater $(P<0.05)$ for calves born from dams fed CON, 32NA, or 16NA versus $48 \mathrm{NA}$.

work was supported by the USDA National Institute of Food and Agriculture Project (Hatch Multistate NC2042; accession number 10012830). The authors state that there are no conflicts of interest.

\section{REFERENCES}

Abdouli, H., and D. M. Schaefer. 1986. Effects of two dietary niacin concentrations on ruminal fluid free niacin concentration, and of supplemental niacin and source of inoculum on in vitro microbial growth, fermentative activity, and nicotinamide adenine dinucleotide pool size. J. Anim. Sci. 62:254-262. https://doi.org/10.2527/ jas1986.621254x.

Akers, R. M. 2002. Lactation and the Mammary Gland. Iowa State University Press, Ames.

AOAC International. 1990. Official Methods of Analysis. 15th ed. AOAC Int., Arlington, VA.

AOAC International. 1998. Official Methods of Analysis. 16th ed. AOAC Int., Gaithersburg, MD.

AOAC International. 2006. Official Methods of Analysis. 18th ed. AOAC Int., Gaithersburg, MD.

Aragona, K. M., C. E. Chapman, A. B. D. Pereira, B. J. Isenberg, R. B. Standish, C. J. Maugeri, R. G. Cabral, and P. S. Erickson. 2016. Prepartum supplementation of nicotinic acid: Effects on health of the dam, colostrum quality, and acquisition of immunity in the calf. J. Dairy Sci. 99:3529-3538. https://doi.org/10.3168/jds.2015 -10598 .

Arthington, J. D., M. B. Cattell, J. D. Quigley III, G. C. McCoy, and W. L. Hurley. 2000. Passive Ig transfer in newborn calves fed colostrum or spray-dried serum protein alone or as a supplement to colostrum of varying quality. J. Dairy Sci. 83:2834-2838. https:// doi.org/10.3168/jds.S0022-0302(00)75183-6.

Aschemann, M., P. Lebzien, L. Hüther, S. Döll, K. Südekum, and S. Dänicke. 2012. Effect of niacin supplementation on digestibility, nitrogen utilization, and milk and blood variables in lactating dairy cows fed a diet with a negative rumen nitrogen balance. Arch. Anim. Nutr. 66:200-214.

Barrington, G. M., T. B. McFadden, M. T. Huyler, and T. E. Besser. 2001. Regulation of colostrogenesis in cattle. Livest. Prod. Sci. 70:95-104. https://doi.org/10.1016/S0301-6226(01)00201-9.

Belibasakis, N. G., and D. Tsirgogianni. 1996. Effects of niacin on milk yield, milk composition, and blood components of dairy cows in hot weather. Anim. Feed Sci. Technol. 64:53-59. https://doi.org/ 10.1016/S0377-8401(96)01052-8.

Benyó, Z., A. Gille, C. L. Bennett, B. E. Clausen, and S. Offermanns. 2006. Nicotinic acid-induced flushing is mediated by activation of epidermal Langerhans cells. Mol. Pharmacol. 70:1844-1849. https: //doi.org/10.1124/mol.106.030833.

Brandon, M. R., D. L. Watson, and A. K. Lascelles. 1971. The mechanism of transfer of Ig into mammary secretion of cows. Aust. J. Exp. Biol. Med. Sci. 49:613-623. https://doi.org/10.1038/icb.1971 .67 .

Burton, J. H., A. A. Hosein, I. McMillan, D. G. Grieve, and B. N Wilkie. 1984. Immunoglobulin absorption in calves as influenced by dietary protein intakes of their dams. Can. J. Anim. Sci 64(5):185-186. https://doi.org/10.4141/cjas84-216.

Campbell, J. M., M. R. Murphy, R. A. Christensen, and T. R. Overton. 1994. Kinetics of niacin supplements in lactating dairy cows. J. Dairy Sci. 77:566-575. https://doi.org/10.3168/jds.S0022 -0302(94)76985-X.

Chen, X. B., and M. J. Gomes. 1992. Estimation of microbial protein supply to sheep and cattle based on urinary excretion of purine 
derivatives - An overview of the technical details. Int. Feed Resources Unit, Rowett Research Institute, Aberdeen, UK.

Dehority, B. A. 2003. Rumen Microbiology. Nottingham University Press, UK.

DeNise, S. K., J. D. Robison, G. H. Stott, and D. V. Armstrong. 1989. Effects of passive immunity on subsequent production in dairy heifers. J. Dairy Sci. 72:552-554. https://doi.org/10.3168/ jds.S0022-0302(89)79140-2.

Dennis, S. M., M. J. Arambel, E. E. Bartley, D. O. Riddell, and A. D. Dayton. 1982. Effect of heated or unheated soybean meal with or without niacin on rumen protozoa. J. Dairy Sci. 65:1643-1646. https://doi.org/10.3168/jds.S0022-0302(82)82391-6.

Di Costanzo, A., J. N. Spain, and D. E. Spiers. 1997. Supplementation of nicotinic acid for lactating Holstein cows under heat stress conditions. J. Dairy Sci. 80:1200-1206. https://doi.org/10.3168/ jds.S0022-0302(97)76048-X.

Doreau, M., and J. F. Ottou. 1996. Influence of niacin supplementation on in vivo digestibility and ruminal digestion in dairy cows. J. Dairy Sci. 79:2247-2254. https://doi.org/10.3168/jds.S0022 -0302(96)76601-8.

Drackley, J. K., D. W. LaCount, J. P. Elliott, T. H. Klusmeyer, T. R. Overton, J. H. Clark, and S. A. Blum. 1998. Supplemental fat and nicotinic acid for Holstein cows during an entire lactation. J. Dairy Sci. 81:201-214. https://doi.org/10.3168/jds.S0022-0302(98)75567 -5 .

Dunn, A., A. Ashfield, B. Earley, M. Welsh, A. Gordon, and S. J. Morrison. 2017. Evaluation of factors associated with immunoglobulin $\mathrm{G}$, fat, protein, and lactose concentrations in bovine colostrum and colostrum management practices in grassland-based dairy systems in Northern Ireland. J. Dairy Sci. 100:2068-2079. https://doi.org/ 10.3168/jds.2016-11724.

Erickson, P. S., M. R. Murphy, and J. H. Clark. 1992. Supplementation of dairy cow diets with calcium salts of long-chain fatty acids and nicotinic acid in early lactation. J. Dairy Sci. 75:1078-1089. https://doi.org/10.3168/jds.S0022-0302(92)77852-7.

Erickson, P. S., M. R. Murphy, C. S. McSweeney, and A. M. Trusk. 1991. Niacin absorption from the rumen. J. Dairy Sci. 74:34923495. https://doi.org/10.3168/jds.S0022-0302(91)78540-8.

Erickson, P. S., A. M. Trusk, and M. R. Murphy. 1990. Effects of niacin source on epinephrine stimulation of plasma nonesterified fatty acid and glucose concentrations, on diet digestibility and on rumen protozoal numbers in lactating dairy cows. J. Nutr. 120:1648-1653. https://doi.org/10.1093/jn/120.12.1648.

Fatahnia, F., A. Shahsavar, H. R. Mirzaei Alamouti, H. Darmani Kohi, H. Amanlou, and M. Ahmadi. 2012. Influence of starch sources in prepartum diet on colostrum quality and blood immunoglobulin concentration in calves. Iran. J. Appl. Anim. Sci. 2:57-61.

Flachowsky, G. 1993. Niacin in dairy and beef cattle nutrition. Arch. Tierernahr. 43:195-213. https://doi.org/10.1080/ 17450399309386036.

Fronk, T. J., and L. H. Schultz. 1979. Oral nicotinic acid as a treatment for ketosis. J. Dairy Sci. 62:1804-1807. https://doi.org/10 .3168/jds.S0022-0302(79)83501-8.

Frye, T. M., S. N. Williams, and T. W. Graham. 1991. Vitamin deficiencies in cattle. Vet. Clin. North Am. Food Anim. Pract. 7:217275. https://doi.org/10.1016/S0749-0720(15)30817-3.

Gulliksen, S. M., K. I. Lie, L. Sølverød, and O. Østerås. 2008. Risk factors associated with colostrum quality in Norwegian dairy cows. J. Dairy Sci. 91:704-712. https://doi.org/10.3168/jds.2007-0450.

Hannah, S. M., and M. D. Stern. 1985. Effect of supplemental niacin or niacinamide and soybean source on ruminal bacterial fermentation in continuous culture. J. Anim. Sci. 61:1253-1263. https://doi .org $/ 10.2527 /$ jas 1985.6151253x.

Harvey, R., and D. Ferrier. 2011. Biochemistry. 5th ed. Lippincott Williams \& Wilkins, Philadelphia, PA.

Horner, J. L., C. E. Coppock, J. R. Moya, J. M. Labore, and J. K. Lanham. 1988. Effects of niacin and whole cottonseed on ruminal fermentation, protein degradability, and nutrient digestibility. J. Dairy Sci. 71:1239-1247. https://doi.org/10.3168/jds.S0022 $-0302(88) 79679-4$.
Horst, R. L. 1986. Regulation of calcium and phosphorus homeostasis in the dairy cow. J. Dairy Sci. 69:604-616. https://doi.org/10 .3168/jds.S0022-0302(86)80445-3.

Hough, R. L., F. D. McCarthy, H. D. Kent, D. E. Eversole, and M. L. Wahlberg. 1990. Influence of nutritional restriction during late gestation on production measures and passive immunity in beef cattle. J. Anim. Sci. 68:2622-2627. https://doi.org/10.2527/1990 $.6892622 \mathrm{x}$.

Huhtanen, P., S. Ahvenjarvi, G. A. Broderick, S. M. Reynal, and K. J. Shingfield. 2010. Quantifying ruminal digestion of organic matter and neutral detergent fiber using the omasal sampling technique in cattle-A meta-analysis. J. Dairy Sci. 93:3203-3215. https://doi .org/10.3168/jds.2009-2988.

Karkoodi, K., and K. Tamizrad. 2009. Effect of niacin supplementation on performance and blood parameters of Holstein cows. S. Afr. J. Anim. Sci. 19:249-259.

Kim, H., E. L. Jacobson, and M. K. Jacobson. 1994. NAD glycohydrolases: A possible function in calcium homeostasis. Mol. Cell. Biochem. 138:237-243. https://doi.org/10.1007/BF00928467.

Littledike, E. T., and J. P. Goff. 1987. Interactions of calcium, phosphorus, magnesium, and vitamin $\mathrm{D}$ that influence the status in domestic meat animals. J. Anim. Sci. 65:1727-1743. https://doi .org/10.2527/jas1987.6561727x.

Loh, K. R., R. E. Shrader, and F. J. Zeman. 1971. Effect of maternal protein deprivation on neonatal intestinal absorption in rats. J. Nutr. 101:1663-1671. https://doi.org/10.1093/jn/101.12.1663.

Morrill, K. M., E. Conrad, A. Lago, J. Campbell, J. Quigley, and H. Tyler. 2012. Nationwide evaluation of quality and composition of colostrum on dairy farms in the United States. J. Dairy Sci 95:3997-4005. https://doi.org/10.3168/jds.2011-5174.

Murphy, M. R. 1982. Analyzing and presenting pH data. J. Dairy Sci. 65:161-163. https://doi.org/10.3168/jds.S0022-0302(82)82165-6.

NRC. 1998. Nutrient Requirements of Swine. 10th rev. ed. Natl. Acad. Press, Washington, DC.

NRC. 2001. Nutrient Requirements of Dairy Cattle. 7th rev. ed. Natl. Acad. Press, Washington, DC.

Niehoff, I. D., L. Hüther, and P. Lebzien. 2009a. Niacin for dairy cattle: A review. Br. J. Nutr. 101:5-19. https://doi.org/10.1017/ S0007114508043377.

Niehoff, I., L. Hüther, P. Lebzien, W. Bigalke, S. Dänicke, and G. Flachowsky. 2009b. Investigations on the effect of a niacin supplementation to three diets differing in forage-to-concentrate ratio on several blood and milk variables of dairy cows. Arch. Anim. Nutr. 63:203-218. https://doi.org/10.1080/17450390902863764.

Phipps, A. J., D. S. Beggs, A. J. Murray, P. D. Mansell, M. A. Stevenson, and M. F. Pyman. 2016. Survey of bovine colostrum quality and hygiene on northern Victorian dairy farms. J. Dairy Sci. 99:8981-8990. https://doi.org/10.3168/jds.2016-11200.

Pires, J. A. A., J. B. Pescara, and R. R. Grummer. 2007. Reduction of plasma NEFA concentration by nicotinic acid enhances the response to insulin in feed-restricted Holstein cows. J. Dairy Sci. 90:4635-4642. https://doi.org/10.3168/jds.2007-0146.

Quigley, J. D. III, J. J. Drewry, and K. R. Martin. 1998. Estimation of plasma volume in Holstein and Jersey calves. J. Dairy Sci. 81:1308-1312.

Riddell, D. O., E. E. Bartley, and A. D. Dayton. 1981. Effect of nicotinic acid on microbial protein synthesis in vitro and on dairy cattle growth and milk production. J. Dairy Sci. 64:782-791. https: //doi.org/10.3168/jds.S0022-0302(81)82648-3.

Riond, J. L. 2001. Animal nutrition and acid-base balance. Eur. J. Nutr. 40:245-254. https://doi.org/10.1007/s394-001-8352-2.

Robison, J. D., G. H. Stott, and S. K. DeNise. 1988. Effects of passive immunity on growth and survival of the dairy heifer. J. Dairy Sci. 71:1283-1287. https://doi.org/10.3168/jds.S0022-0302(88)79684 -8 .

Schwab, E. C., D. Z. Caraviello, and R. D. Shaver. 2005. Review: A meta-analysis of lactation responses to supplemental dietary niacin in dairy cows. Prof. Anim. Sci. 21:239-247. https://doi.org/10 .15232/S1080-7446(15)31214-6.

Toghyani, E., and A. Moharrery. 2015. Effect of various levels of dietary protein in transition period on colostrum quality and serum 
immunoglobulin concentration in Holstein cows and their newborn calves. Ann. Anim. Sci. 15:493-504. https://doi.org/10.2478/aoas $-2014-0085$.

Topps, J. H., and R. C. Elliott. 1965. Nitrogen metabolism of cattle and sheep in Southern Africa. Outlook Agric. 4:310-315. https:// doi.org/10.1177/003072706500400607.

Tunaru, S., J. Kero, A. Schaub, C. Wufka, A. Blaukat, K. Pfeffer, and S. Offermanns. 2003. PUMA-G and HM74 are receptors for nicotinic acid and mediate its anti-lipolytic effect. Nat. Med. 9:352355. https://doi.org/10.1038/nm824.

Valadares, R. F. D., G. A. Broderick, S. C. V. Filho, and M. K. Clayton. 1999. Effect of replacing alfalfa silage with high moisture corn on ruminal protein synthesis estimated from excretion of total purine derivatives. J. Dairy Sci. 82:2686-2696. https://doi.org/10 .3168/jds.S0022-0302(99)75525-6.

Valadares, R. F. D., S. C. Valadares Filho, L. C. Gonçalves, N. Rodríguez, and I. Sampaio. 1997. Levels of protein in diets of bovines. 4. Concentrations of ruminal ammonia and plasma urea, and excretion of urea and creatinine. Rev. Bras. Zootec. 26:1270-1278.

Van Soest, P. J., J. B. Robertson, and B. A. Lewis. 1991. Methods for dietary fiber, neutral detergent fiber, and nonstarch polysaccharides in relation to animal nutrition. J. Dairy Sci. 74:3583-3597.

Williams, A. G., and G. S. Coleman. 1992. The Rumen Protozoa. Springer-Verlag, New York, NY.
Yuan, K., R. D. Shaver, S. J. Bertics, M. Espineira, and R. R. Grummer. 2012. Effect of rumen-protected niacin on lipid metabolism, oxidative stress, and performance of transition dairy cows. J. Dairy Sci. 95:2673-2679. https://doi.org/10.3168/jds.2011-5096.

Yuan, K., R. D. Shaver, M. Espineira, and S. J. Bertics. 2011. Effect of a rumen-protected niacin product on lactation performance by dairy cows during summer in Wisconsin. Prof. Anim. Sci. 27:190194. https://doi.org/10.15232/S1080-7446(15)30473-3.

Zimbelman, R. B., L. H. Baumgard, and R. J. Collier. 2010. Effects of encapsulated niacin on evaporative heat loss and body temperature in moderately heat-stressed lactating Holstein cows. J. Dairy Sci. 93:2387-2394. https://doi.org/10.3168/jds.2009-2557.

Zimmerman, C. A., A. H. Rakes, T. E. Daniel, and B. A. Hopkins. 1992. Influence of dietary protein and supplemental niacin on lactational performance of cows fed normal and low fiber diets. J. Dairy Sci. 75:1965-1978. https://doi.org/10.3168/jds.S0022 -0302(92)77956-9

\section{ORCIDS}

K. M. Aragona @ https://orcid.org/0000-0003-3674-838X

E. M. Rice (ํ) https://orcid.org/0000-0002-1642-8373

P. S. Erickson ๑ https://orcid.org/0000-0002-8028-3279 